\title{
Chemical Composition and Product Quality Control of Turmeric (Curcuma longa L.)
}

\author{
Shiyou Li*,1, Wei Yuan', Guangrui Deng ${ }^{1}$, Ping Wang ${ }^{1}$, Peiying Yang ${ }^{2}$ and Bharat B. Aggarwal ${ }^{3}$ \\ ${ }^{I}$ National Center for Pharmaceutical Crops, Arthur Temple College of Forestry and Agriculture, Stephen F. Austin State \\ University, Nacogdoches, TX 75972, USA \\ ${ }^{2}$ Department of General Oncology, Integrative Medicine Program, M.D. Anderson Cancer Center, University of Texas, \\ Houston, TX 77030, USA \\ ${ }^{3}$ Cytokine Research Laboratory, Department of Experimental Therapeutics, M.D. Anderson Cancer Center, University \\ of Texas, Houston, TX 77030, USA
}

\begin{abstract}
Chemical constituents of various tissues of turmeric (Curcuma longa L.) have been extensively investigated. To date, at least 235 compounds, primarily phenolic compounds and terpenoids have been identified from the species, including 22 diarylheptanoids and diarylpentanoids, eight phenylpropene and other phenolic compounds, 68 monoterpenes, 109 sesquiterpenes, five diterpenes, three triterpenoids, four sterols, two alkaloids, and 14 other compounds. Curcuminoids (diarylheptanoids) and essential oils are major bioactive ingredients showing various bioactivities in in vitro and in vivo bioassays. Curcuminoids in turmeric are primarily accumulated in rhizomes. The essential oils from leaves and flowers are usually dominated by monoterpenes while those from roots and rhizomes primarily contained sesquiterpenes. The contents of curcuminoids in turmeric rhizomes vary often with varieties, locations, sources, and cultivation conditions, while there are significant variations in composition of essential oils of turmeric rhizomes with varieties and geographical locations. Further, both curcuminoids and essential oils vary in contents with different extraction methods and are unstable with extraction and storage processes. As a result, the quality of commercial turmeric products can be markedly varied. While curcumin (1), demethoxycurcumin (2), and bisdemethoxycurcumin (5) have been used as marker compounds for the quality control of rhizomes, powders, and extract ("curcumin") products, $A r$-turmerone (99), $\alpha$-turmerone (100), and $\beta$-turmerone (101) may be used to control the product quality of turmeric oil and oleoresin products. Authentication of turmeric products can be achieved by chromatographic and NMR techniques, DNA markers, with morphological and anatomic data as well as GAP and other information available.
\end{abstract}

Keywords: Turmeric, Curcuma longa L., rhizomes, ground turmeric, turmeric oils, turmeric oleoresin, curcuminoids, curcumin, sesquiterpenes, marker compounds, adulteration, standardization.

\section{INTRODUCTION}

Turmeric (Curcuma longa L.) is a rhizomatous herbaceous perennial plant of the ginger family, Zingiberaceae. It is native to tropical South Asia but is now widely cultivated in the tropical and subtropical regions of the world. The deep orange-yellow powder known as turmeric is prepared from boiled and dried rhizomes of the plant. It has been commonly used as spice and medicine (Rhizome Curcumae Longae), particularly in Asia. In Ayurveda medicine, turmeric is primarily used as a treatment for inflammatory conditions and in traditional Chinese medicine, it is used as stimulant, aspirant, carminative, cordeal, emenagogue, astringent, detergent, diuretic and martirnet [1-3]. In India and China, wild turmeric ( $C$. aromatica Salisb., commonly called as Kasthuri manjal or yujin) is sometimes used as turmeric production [4]. This species is known as $C$. wenyujin Y.H. Chen et C. Ling in China. It was also occasionally used to substitute Rhizome Curcumae

*Address correspondence to this author at the National Center for Pharmaceutical Crops, Arthur Temple College of Forestry and Agriculture, Stephen F. Austin State University, Nacogdoches, TX 75972, USA;

Tel: 936-468-2071, 936-468-5600; Fax: 936-468-7058;

E-mail: lis@sfasu.edu
Longae but recently it has been separated as Rhizoma Wenyujin Concisum in the 2005 version of the Pharmacopoeia of People's Republic of China [5]. In Thailand and some other countries, C. domestica Val. is also used as the scientific name of turmeric [6-8] although it is recognized as a synonym of C. longa [9].

There are extensive in vitro and in vivo investigations on turmeric extracts (ethanol, methanol, water, and ethyl acetate extracts) or "pure" active "curcumin" (actually it was a mixture of three major curcumnnioids in many cases) powder over the last half century. The role of curcumin (1), one of the most studied chemopreventive agents, on antiinflammatory and cancer activity has been well appreciated [3, 10-19]. Data from cell culture, animal research, and clinical trials indicate that curcumin may have potential as a therapeutic agent in diseases such as inflammatory bowel disease, pancreatitis, arthritis, and chronic anterior uveitis [3, 20]. The anti-cancer effect has been reported in a few clinical trials, mainly as a chemoprevention agent in colon and pancreatic cancer, cervical neoplasia and Barrets metaplasia [16]. The compound modulates several molecular targets and inhibits transcription factors (NF-kB, AP-1), enzymes (COX-1, COX-2, LOX), cytokines (TNF, IL-1, IL-6) and 
antiapoptotic genes (BCL2, BCL2L1) [21-24]. As a result, curcumin (1) is able to induce apoptosis and has antiangiogenic activity $[25,26]$.

Turmeric extracts or the active curcuminoids have also shown hepato- and cardioprotective [27, 28], hypoglycemic [29, 30], anti-amyloidogenic [31], antifungal [32], parasiticidal $[33,34]$, antioxidant $[35,36]$, and chemo-resistance and radio-resistance activities [16]. Recent in vitro and in vivo studies and clinical trials in China and USA suggest that curcumin might be one of the most promising compounds for the development of Alzheimer's disease therapies [37]. Accumulating evidences suggest that curcumin (1) may regulate lipid metabolism, which plays a central role in the development of obesity and its complications [38]. Recently, it was found that curcumin (1) and demethoxycurcumin (2) can reduce lead-induced memory deficits in rates [39]. Turmeric oils/oleoresin or a major compound ar-turmerone (99) have shown antimicrobial [40-43], larvicidal [44], and antioxidant activities [45]. Essential oils of Curcuma also exerts triglyceride-lowering activity on serum as well as liver triglycerides [46].

Curcuma longa is often cultivated to harvest rhizomes (Fig. 1) for ground turmeric powder as a spice and food coloring agent (used alone or in mustard paste or curry powder). The plant has also been recognized as a pharmaceutical crop for production of standardized therapeutic extracts (STEs) or small therapeutic molecules (STMs) [47]. India is the largest producer of turmeric supplying over $90 \%$ of the world's demand [48]. The country produced about $716,900 \mathrm{Mt}$ of turmeric from approximately 161,300 hectares of crops during 2004-2005 [49]. China also has cultivated turmeric for both domestic use and export. There are about 70 cultivars or varieties of C. longa cultivated in India, some important regional trade varieties of turmeric are 'Rajapuri', 'Duggirala', 'Cuddappah', 'Berhampur', 'Erode', 'Nizamabad', 'Koraput', 'Kasturi', 'Chaya', 'Kodur', 'Salem', 'Waigon', 'Alleppey', 'Karur', 'Tekurpeta' [2]. Turmeric is valued primarily for curcumin (1). Thus, curcumin (1) content has been an important factor in developing and selecting cultivar or variety for turmeric production and in determining the price of turmeric [50]. For example, PTS-10 and PTS-24, two clones were selected for rhizome yield and high dry recovery and both can yield $9.3 \%$ curcumin (1) [51]. Curcumin (1) can also be produced by chemical synthesis but the synthetic curcumin (1) is not used as a food additive. The main pharmaceutical products from turmeric are dried whole rhizomes, ground turmeric, turmeric oils, turmeric oleoresin, and curcumin (maybe actually mixture of three curcuminoids) $[49,52]$ (Table 1).

\section{CHEMICAL CONSTITUENTS}

Of 110 species of the genus Curcuma L., only about 20 species have been studied phytochemically [53]. Curcuma longa is the most chemically investigated species of Curcuma. To date, at least 235 compounds, primarily phenolic compounds and terpenoids have been identified, including diarylheptanoids (including commonly known as curcuminoids), diarylpentanoids, monoterpenes, sesquiterpenes, diterpenes, triterpenoids, alkaloid, and sterols, etc.

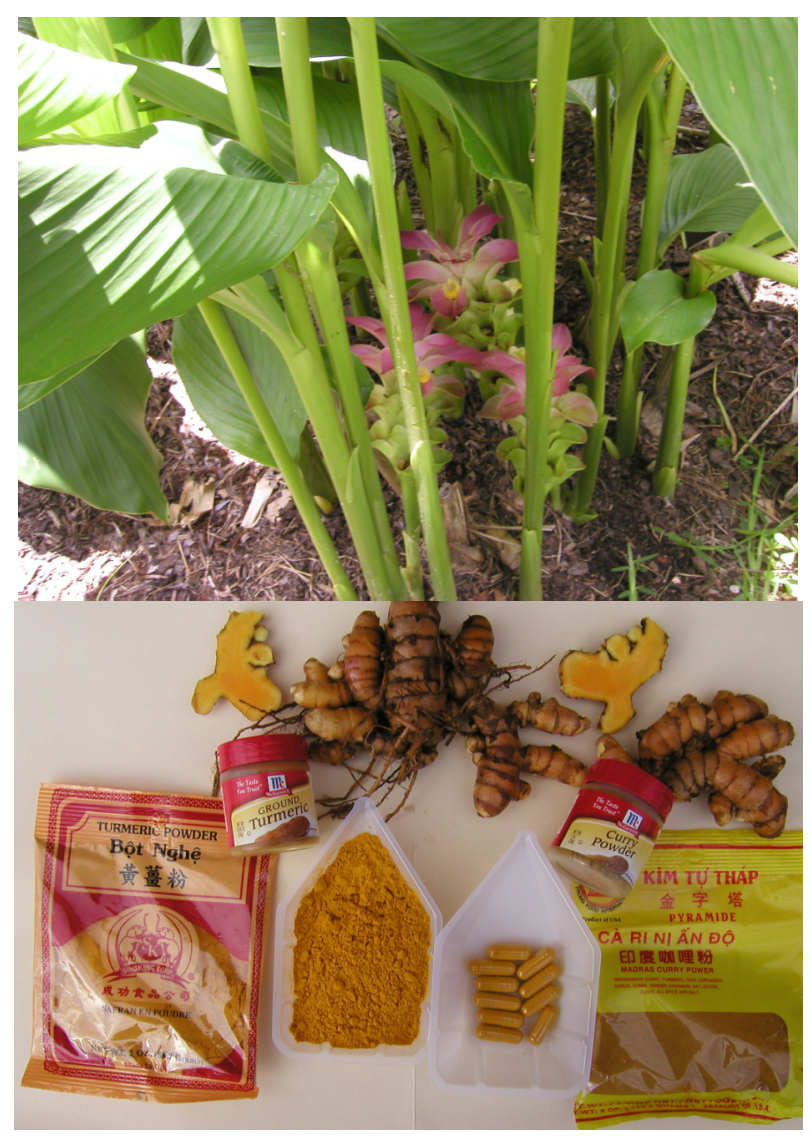

Fig. (1). Curcuma longa is primarily cultivated for turmeric rhizomes and their products (The upper picture shows the plants cultivated at the SFA Mast Arboretum, Stephen F. Austin State University in Nacogdoches, Texas, USA and the lower picture shows rhizomes and ground turmeric as well as curry powder. Photos by S.Y. Li).

\section{Phenolic Compounds}

\section{Diarylheptanoids and Diarylpentanoids}

Over 300 diarylheptanoids have been reported in the family Zingiberaceae and some non-closely related families [54]. Curcuminoids belong to the group of diarylheptanoids (or diphenylheptanoids) having an aryl-C7-aryl skeleton (119). These yellow pigments are usually used as food coloring agents and they are the main active compounds in turmeric. Usually, these polyphenols are present in $3-15 \%$ of turmeric rhizomes with curcumin (1) as the principal compound. Curcumin $\left(\mathrm{C}_{21} \mathrm{H}_{20} \mathrm{O}_{5}\right)(\mathbf{1})$, also known as diferuloyl methane or 1,6-heptadiene-3,5-dione-1,7-bis(4-hydroxy-3-methoxyphenyl)-(1E,6E), was isolated in 1815 [49] and its chemical structure was determined in 1910 [55]. The compound is a yellow-orange powder with a molecular weight of 368.37 . It is water insoluble but can be dissolved well in ethanol, methanol, actone, and dimethysulfoxide. Commercial "curcumin" is usually a mixture of three curcuminoids. For example, the composition of a commercial "curcumin" is about $71.5 \%$ curcumin (curcumin I) (1), 19.4\% demethoxycurcumin (curcumin II) (2), and $9.1 \%$ bisdemethoxycurcumin (curcumin III) (5) [56]. These three major curcuminoids are also found in some other species of Curcuma but have lower concentrations, e.g., C. amada Roxb. [57], C. aeruginosa 
Table 1. Main products of turmeric (Curcuma longa)

\begin{tabular}{|c|c|c|}
\hline Product & Description & Uses \\
\hline $\begin{array}{l}\text { Dried } \\
\text { Whole Rhi- } \\
\text { zome }\end{array}$ & $\begin{array}{l}\text { Preparation: mother rhizomes (egg-shipped primary rhizomes) and finger rhizomes (cylindrical and } \\
\text { multibranched secondary rhizomes) are usually boiled separately for about } 40-60 \text { min under slightly } \\
\text { alkaline conditions in copper, galvanized iron or earth vessels and then sun-dried on bamboo mats } \\
\quad \text { for } 10-15 \text { days to reduce the moisture to } 10-11 \% \\
\text { Harvest: usually } 7-9 \text { months after planting during January-March } \\
\text { Appearance: orange-brown, pale yellow or red-yellow } \\
\text { Chemical Composition: may contain } 3-15 \% \text { cucuminoids and } 1.5 \text { to } 5 \% \text { essential oils }\end{array}$ & $\begin{array}{l}\text { Medicine (Rhizoma Cur- } \\
\text { cumae Longae) and process } \\
\text { of other turmeric products }\end{array}$ \\
\hline $\begin{array}{l}\text { Ground } \\
\text { Turmeric }\end{array}$ & $\begin{array}{l}\text { Preparation: Powder is prepared from dried finger rhizomes }(60-80 \text { mesh) } \\
\text { Appearance: yellow or red-yellow powder } \\
\text { Chemical Composition: The contents of active ingredients curcuminoids and essential oils may decrease } \\
\text { during the process and exposure to light, it is appropriate to pack the powder in a UV protective con- } \\
\text { tainer (e.g., fiber hard drums, glass packs, etc.) }\end{array}$ & $\begin{array}{l}\text { Spice: as alone or in curry } \\
\text { powder and pastes } \\
\text { dye: for food, textile, cos- } \\
\text { metic } \\
\text { Medicine: e.g., in } \\
\text { Ayurveda, } \\
\text { medicine } \\
\text { Dietary supplement }\end{array}$ \\
\hline Tumeric Oils & $\begin{array}{l}\text { Preparation: Extract from dried rhizomes (ground turmeric) or leaves by steam distillation or supercriti- } \\
\quad \text { cal } \mathrm{CO}_{2} \text { extraction } \\
\text { Chemical Composition: essential oils from leaves is usually dominated by monoterpenes while the oil } \\
\quad \text { from rhizomes mainly contains sesquiterpenes } \\
\text { Appearance: yellow to brown viscous liquid } \\
\text { Refractive Index: } 1.4850-1.5250 \\
\text { Flash Point: } 78^{\circ} \mathrm{C} \\
\text { Solubility in Water: insoluble }\end{array}$ & $\begin{array}{l}\text { Spice, medicine, and die- } \\
\text { tary supplement }\end{array}$ \\
\hline $\begin{array}{l}\text { Tumeric } \\
\text { Oleoresin }\end{array}$ & $\begin{array}{l}\text { Preparation: Extract from dried rhizomes by solvent extraction with aceone, dichloromethane, } 1,2- \\
\quad \text { dichloroethane, methanol, ethanol, isopropanol and light petroleum (hexanes) or supercritical } \\
\quad \mathrm{CO}_{2} \text { extraction. Graded by the content of curcuminoids or color value } \\
\text { Chemical Composition: } 37-55 \% \text { curcuminoids and up to } 25 \% \text { essential oil } \\
\text { Appearance: yellow-dark reddish brown oily fluids } \\
\text { Refractive Index: } 1.4850-1.5250 \\
\text { Flash Point: } 78^{\circ} \mathrm{C} \\
\text { Solubility in Water: insoluble }\end{array}$ & $\begin{array}{l}\text { Food coloring, medicine, } \\
\text { and dietary supplement }\end{array}$ \\
\hline $\begin{array}{l}\text { Curcumin } \\
\text { (turmeric } \\
\text { yellow, } \\
\text { kurkum) }\end{array}$ & $\begin{array}{l}\text { Preparation: obtained by solvent extraction from ground turmeric rhizomes and purification of the extract } \\
\text { by crystallization. The suitable solvents include aceone, carbon dioxide, ethanol, ethyl acetate, hex- } \\
\text { ane, methanol, , isopropanol } \\
\text { Chemical Composition: the product is often the mixture of curcumin and its demethoxy- and bisde- } \\
\text { methoxy- derivatives in turmeric in varying proportions. The three major curcuminoids may account } \\
\text { no less than } 90 \% \text {. Minor compounds may include oils and resins naturally occurring in turmeric rhi- } \\
\text { zomes } \\
\text { Appearance: yellowish to orange red crystalline powder } \\
\text { Molecular Formula: } \mathrm{C}_{21} \mathrm{H}_{20} \mathrm{O}_{6} \\
\text { Molecular Weight: } 368.38 \\
\text { Solubility in Water: insoluble }\end{array}$ & $\begin{array}{l}\text { Medicine and dietary sup- } \\
\text { plement }\end{array}$ \\
\hline
\end{tabular}

Roxb. [58, 59], C. aromatica [53], C. chuanyujin Roxb. [60], C. heyneana Val. \& Zijp. [59], C. mangga Val. \&. Zijp. [59], C. soloensis Val. [59], C. xanthorrhiza Roxb. [58, 61], and Curcuma zedoaria (Berg.) Rosc. [62]. It expected that these common curcuminoids may occur in some other species of Curcuma although there are no chemical investigations conducted on most of the 110 species of the genus. Some minor and rare curcuminoids of $C$. longa or their analogs may be identified in other species. For example, cyclocurcumin (17) with cyclization of the seven-carbon unit as a pyrone ring, was only found in $C$. longa [53, 63]. Recently, 3'demthoxycyclocurcumin was isolated from $C$. xanthorrhiza [64]. 


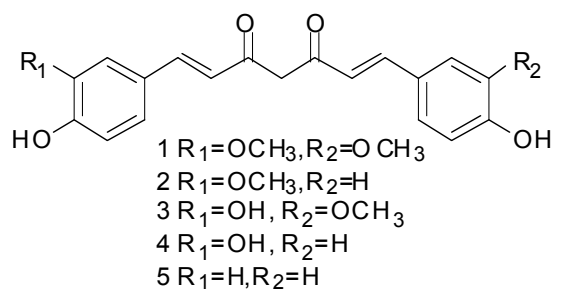<smiles>COc1cc(CCC(=O)CC(=O)CCc2ccc(O)c(OC)c2)ccc1O</smiles>

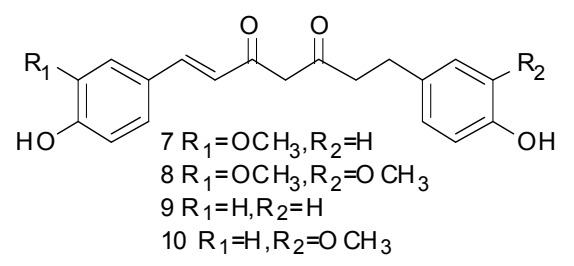<smiles>O=C(/C=C/c1ccc(O)cc1)CC(O)CC(=O)c1ccc(O)cc1</smiles>

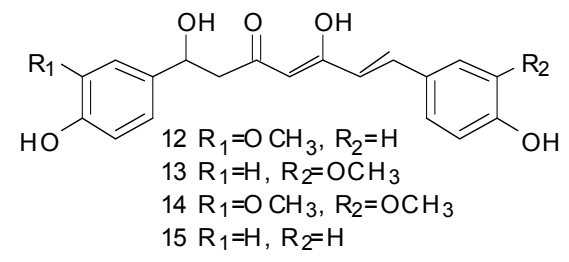<smiles>[R]c1cc(/C=C/C2=CC(=O)CC(c3ccc(O)c([R2])c3)O2)ccc1O</smiles><smiles>COc1cc(/C=C/C=C/C(=O)/C=C/c2ccc(O)c(OC)c2)ccc1O</smiles><smiles>[R]c1cc(/C=C/C(=O)/C=C/c2ccc(O)c([R2])c2)ccc1O</smiles>

$20 \mathrm{R}_{1}=\mathrm{H}, \mathrm{R}_{1}=\mathrm{H}$

$21 \mathrm{R}_{1}=\mathrm{OCH}_{3}, \mathrm{R}_{1}=\mathrm{H}$

$22 \mathrm{R}_{1}=\mathrm{OCH}_{3}, \mathrm{R}_{1}=\mathrm{OCH}_{3}$<smiles>[R2]c1cc(/C=C/C(=O)COC(=O)/C=C/c2ccc(O)c([R])c2)ccc1O</smiles><smiles>COc1cc(/C=C/C(C)=O)ccc1/C=C/C(=O)O</smiles>

\begin{tabular}{|c|c|c|c|}
\hline No. & Compound Name & Compound Type & Ref. \\
\hline 1 & curcumin (curcumin I) & Diarylheptanoid & {$[65,66]$} \\
\hline 3 & 1-(4-hydroxy-3-methoxyphenyl)-7-(3, 4-dihydroxyphenyl)-1, 6-heptadiene-3, 5-dione & Diarylheptanoid & {$[67]$} \\
\hline 4 & 1-(4-hydroxyphenyl)-7-(3, 4-dihydroxyphenyl)-1, 6-heptadiene-3, 5-dione & Diarylheptanoid & {$[67]$} \\
\hline 6 & tetrahydroxycurcumin & Diarylheptanoid & [65] \\
\hline 7 & 5-hydroxyl-1-(4-hydroxy-3-methoxyphenyl)-7-(4-hydroxyphenyl)-4,6-heptadiene-3-one & Diarylheptanoid & {$[68]$} \\
\hline 8 & 5-hydroxyl-1,7-bis(4-hydroxy-3-methoxyphenyl)-4,6-heptadiene-3-one & Diarylheptanoid & {$[68,69]$} \\
\hline 9 & 1,7-bis(4-hydroxyphenyl)-1-heptene-3,5-dione & Diarylheptanoid & [68] \\
\hline
\end{tabular}


Contd....

\begin{tabular}{|c|c|c|c|}
\hline No. & Compound Name & Compound Type & Ref. \\
\hline 12 & 1,5-dihydroxy-1-(4-hydroxy-3-methoxyphenyl)-7-(4-hydroxyphenyl)-4,6-heptadiene-3-one & Diarylheptanoid & {$[67]$} \\
\hline 13 & 1,5-dihydroxy-1-(4-hydroxyphenyl)-7-(4-hydroxy-3-methoxyphenyl)-4,6-heptadiene-3-one & Diarylheptanoid & [67] \\
\hline 15 & 1,5-dihydroxy-1,7-bis(4-hydroxyphenyl)-4,6-heptadiene-3-one & Diarylheptanoid & {$[67]$} \\
\hline 16 & 1,5-epoxy-3-carbonyl-1,7-bis(4-hydroxyphenyl)-4,6-heptadiene & Diarylheptanoid & [7] \\
\hline 17 & cyclocurcumin & Diarylheptanoid & {$[70]$} \\
\hline 18 & 1,7-bis(4-hydroxy-3-methoxyphenyl)-1,4,6-heptatrien-3-one & Diarylheptanoid & [69] \\
\hline 21 & 1-(4-hydroxy-3-methoxyphenyl)-5-(4-hydroxyphenyl)-1, 4-pentadiene-3-one & Diarylpentanoid & {$[67]$} \\
\hline 22 & 1,5-bis(4-hydroxy-3-methoxyphenyl)-penta-(1E,4E)-1,4-dien-3-one & Diarylpentanoid & {$[72]$} \\
\hline 23 & 4"-(4"'-hydroxyphenyl)-2"-oxo-3"-butenyl-3-(4'-hydroxyphenyl-3'-methoxy)-propenoate & Phenylpropene & [73] \\
\hline 24 & 4"-(4"'-hydroxyphenyl-3-methoxy)-2"-oxo-3"-butenyl-3-(4'-hydroxyphenyl)-propenoate & Phenylpropene & [73] \\
\hline 25 & calebin-A & Phenylpropene & {$[65]$} \\
\hline 26 & (E)-4-(4-hydroxy-3-methoxyphenyl)but-3-en-2-one & Phenylpropene & {$[72]$} \\
\hline 27 & (E)-ferulic acid & Phenylpropene & {$[72]$} \\
\hline
\end{tabular}

There are three diarylpentanoids (or diphenylpentanoids) with a five-carbon chain between two phenyl groups (20-22).

Curcuminoids have shown different activities. A recent study suggested that curcumin (1) had the relative higher potency for suppression of tumor necrosis factor (TNF)induced nuclear factor-kB (NF- $\mathrm{kB})$ activation than that of demethoxycurcumin (2) and bisdemethoxycurcumin (5), while tetrahydrocurcumin (6) without the conjugated bonds in the central seven-carbon chain was completely inactive [21]. The results suggest that the methoxy groups on the phenyl ring has critical role but conjugated bonds in the central seven-carbon chain also important for curcuminoids' NF- $\kappa B$ activity [21]. However, the suppression of proliferation of various tumor cell lines by curcumin (1), demethoxycurcumin (2), and bisdemethoxycurcumin (5) was found to be comparable; indicating the methoxy groups play minimum role in the anti-proliferative effects of curcuminoids [21]. A further investigation of structure-activity relationship is needed by using pure curcuminoids.

It was interesting to mention that synergistic effect of mixture of compounds in turmeric had been observed. For example, it was found that methanolic and chloroformic extracts of turmeric demonstrated nematocidal activity against Toxocara canis [63]. All the substances including cyclocur- cumin (17) did not show activity when applied independently, but the activity was observed when they were mixed, suggesting a synergistic action between them.

Because the difficulty in separation of three curcuminoids each other, the commercially pure compounds of curcumin (1), demethoxycurcumin (2), and bidemethoxycurcu$\min (\mathbf{5})$ available as authentic samples are limited. According to our analysis, the commercial "pure" curcumin (1) (labeled as $94 \%$ ) actually has only purity of about $70 \%$. Therefore, at least some existing studies and discoveries on "curcumin" actually used the mixture of three curcuminoids. However, a pure ( $>95 \%)$ curcumin (1) becomes important for bioassays and mechanism investigations as well as clinical trials. Research on bioactivity of curcuminoids are primarily focused on the above three major curcuminoids $(\mathbf{1}, \mathbf{2}$, and $\mathbf{5}$ ), and bioactivities of minor curcuminoids remain elusive.

\section{Phenylpropenes and Other Phenolic Compounds}

Six monomeric phenylpropenes (23-28), vanillic acid (29), and vanillin (30) were identified in C. longa.

\section{Terpenes}

To date, at least 185 compounds of terpenes have been isolated or detected from leaves, flowers, roots and rhizomes 
of C. longa, including 68 monoterpenes (31-98), 109 sesquiterpenes (99-207), five diterpenes (208-212), and three triterpenoids (213-215).

\section{Monoterpenes}

The volatile oils from leaves and flowers of $C$. longa were usually dominated by monoterpenes, particularly $p$ cymene (31), $\beta$-phellandrene ( $\beta$-felandrene) (35), terpinolene (terpenoline) (40), $p$-cymen-8-ol (55), cineole (77), and myrcene (82) while the major part of the oil from roots and rhizomes contained sesquiterpenes [49, 74, 75]. This chemical characteristic can be useful in identification of leaves or flowers of $C$. longa used to substitute its rhizome for turmeric oil production. In total, 68 monoterpenes (31-98) have been identified from various tissues of $C$. longa [75-82].<smiles></smiles><smiles>C=CC1CCC(C)C(=O)C1</smiles><smiles>C=C(C)C1=CC=C(C)CC1</smiles>

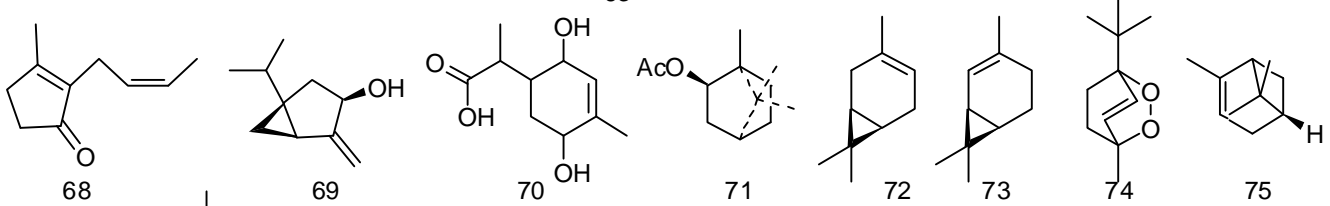

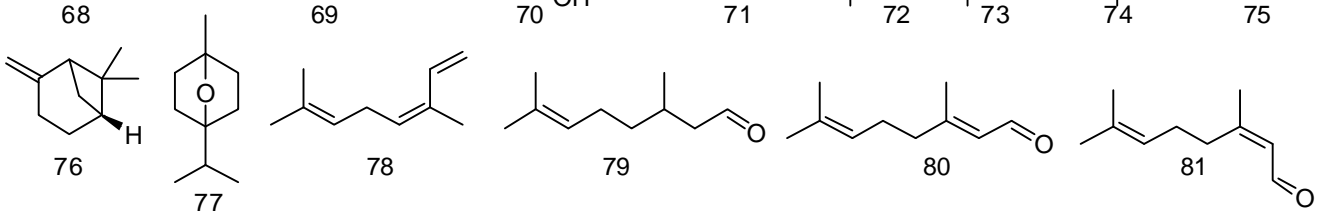<smiles>C=CC(=C)CCC=C(C)C</smiles>

82<smiles>CC(C)=CCC/C(C)=C/CO</smiles>

86

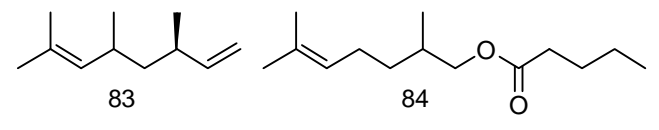<smiles>CC(C)=CCC/C(C)=C\CO</smiles><smiles>C=CC(C)(C)C(=O)C=C(C)C</smiles>

87

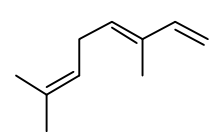

88

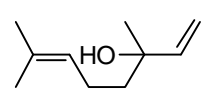

89<smiles>CC(=O)OC/C=C(/C)CC/C=C(/C)C(=O)O</smiles><smiles>CC12CCC(CC1=O)C2(C)C</smiles><smiles>CC(C)=CCC/C(C)=C/CC(C)O</smiles>

91

92<smiles>C/C(=C\CC/C(C)=C/CO)CO</smiles>

97<smiles>CC=CC(C)C(C)C=CC</smiles>

98 


\begin{tabular}{|c|c|c|c|}
\hline No. & Compound Name & Compound Type & Ref. \\
\hline 31 & p-cymene* & Monoterpenoid & {$[77]$} \\
\hline 32 & m-cymene $*$ & Monoterpenoid & {$[78]$} \\
\hline 33 & $\alpha$-terpinene* & Monoterpenoid & {$[78]$} \\
\hline 34 & $\gamma$-terpinene* & Monoterpenoid & {$[78]$} \\
\hline 35 & $\beta$-phellandrene* & Monoterpenoid & {$[78]$} \\
\hline 36 & $p$-mentha-1,4(8)-diene* & Monoterpenoid & [79] \\
\hline 37 & terpinen-4-ol* & Monoterpenoid & [79] \\
\hline 38 & 4-terpinol* & Monoterpenoid & {$[80]$} \\
\hline 39 & limonene* & Monoterpenoid & {$[81]$} \\
\hline 40 & terpinolene* & Monoterpenoid & {$[81]$} \\
\hline 41 & thymol* & Monoterpenoid & {$[78]$} \\
\hline 42 & phellandrol* & Monoterpenoid & {$[77]$} \\
\hline 43 & carvacrol* & Monoterpenoid & [81] \\
\hline 44 & $(E)$-carveol* & Monoterpenoid & {$[81]$} \\
\hline 45 & $\gamma$-terpineol* & Monoterpenoid & {$[79]$} \\
\hline 46 & menthol & Monoterpenoid & {$[76]$} \\
\hline 47 & 1,3,8-paramenthatriene & Monoterpenoid & {$[75]$} \\
\hline 48 & p-methylacetophenone & Monoterpenoid & {$[75]$} \\
\hline 49 & piperitone & Monoterpenoid & {$[76]$} \\
\hline 50 & $o$-cymene* & Monoterpenoid & [79] \\
\hline 51 & carvone* & Monoterpenoid & {$[77]$} \\
\hline 52 & $p$-menth-8-en-2-one* & Monoterpenoid & {$[81]$} \\
\hline 53 & $\alpha$-thujene* & Monoterpenoid & {$[78]$} \\
\hline 54 & $\alpha$-terpineol* & Monoterpenoid & {$[77]$} \\
\hline 55 & p-cymen-8-ol* & Monoterpenoid & [79] \\
\hline 56 & $p$-meth-8-en-2-one* & Monoterpenoid & [79] \\
\hline 57 & piperitone epoxide* & Monoterpenoid & [79] \\
\hline 58 & sylvestrene* & Monoterpenoid & [79] \\
\hline 59 & menthofuran* & Monoterpenoid & {$[77]$} \\
\hline 60 & $\beta, \beta$-dimethylstyrene & Monoterpenoid & {$[76]$} \\
\hline 61 & camphor & Monoterpenoid & {$[76]$} \\
\hline 62 & teresantalol & Monoterpenoid & {$[76]$} \\
\hline 63 & benzene, 1-methyl-4-(1-methylpropyl) & Monoterpenoid & {$[76]$} \\
\hline 64 & 2-norpinanone* & Monoterpenoid & {$[81]$} \\
\hline 65 & borneol* & Monoterpenoid & {$[78]$} \\
\hline 66 & bornyl acetate* & Monoterpenoid & {$[81]$} \\
\hline 67 & $(E)$-chrysanthenyl acetate* & Monoterpenoid & {$[81]$} \\
\hline 68 & $(Z)$-cinerone* & Monoterpenoid & {$[18]$} \\
\hline
\end{tabular}


Contd....

\begin{tabular}{|c|c|c|c|}
\hline No. & Compound Name & Compound Type & Ref. \\
\hline 69 & (Z)-sabinol* & Monoterpenoid & {$[18]$} \\
\hline 71 & camphene* & Monoterpenoid & {$[78]$} \\
\hline 72 & 3 -carene* & Monoterpenoid & {$[81]$} \\
\hline 74 & ascaridole* & Monoterpenoid & {$[81]$} \\
\hline 75 & $\alpha$-pinene* & Monoterpenoid & [77] \\
\hline 76 & $\beta$-pinene* & Monoterpenoid & [79] \\
\hline 80 & geranial* & Monoterpenoid & [78] \\
\hline 81 & neral* & Monoterpenoid & {$[78]$} \\
\hline 82 & myrcene* & Monoterpenoid & {$[78]$} \\
\hline 83 & $R$-citronellene* & Monoterpenoid & [79] \\
\hline 84 & citronellyl pentanoate* & Monoterpenoid & {$[77]$} \\
\hline 85 & nerol* & Monoterpenoid & [77] \\
\hline 86 & geraniol & Monoterpenoid & {$[76]$} \\
\hline 91 & geranic acid & Monoterpenoid & {$[76]$} \\
\hline 92 & geranyl acetate & Monoterpenoid & {$[76]$} \\
\hline 93 & 3-bornanone & Monoterpenoid & [76] \\
\hline 94 & 4,8-dimethyl-3,7-nonadien-2-ol & Monoterpenoid & {$[76]$} \\
\hline 95 & 3,4,5,6-tetramethyl-2,5-octadiene & Monoterpenoid & {$[76]$} \\
\hline 96 & 3,7-dimethyl-6-nonenal & Monoterpenoid & [76] \\
\hline 97 & 2,6-dimethyl-2,6-octadiene-1,8-diol & Monoterpenoid & {$[76]$} \\
\hline 98 & 4,5-dimethyl-2,6-octadiene & Monoterpenoid & [76] \\
\hline
\end{tabular}

\section{Sesquiterpenes}

Dried turmeric rhizomes usually yields 1.5 to $5 \%$ essential oils which are dominated by sesquiterpenes and are responsible for its aromatic taste and smell. $A r$-turmerone (99), $\alpha$-turmerone (100) [83], and $\beta$-turmerone (101) [83] are major ketonic sesquiterpenes of essential oils, and these compounds may account for at least $40 \%$ of essential oils of turmeric rhizomes [84-86]. Two sesquiterpene ketoalcholsturmeronol A (121) and turmeronol B (122) were isolated from the dried turmeric rhizome [87]. To date, 109 compounds of sesquiterpenes have been identified, belonging to various types: 54 bisabolanes (99-152) $[15,16,72-80,82$, 83, 87-93], six germacranes (153-158) [77, 78, 90], seven guaianes (159-165) [72, 90], four selinanes (166-169) [76, 79], three santalanes (170-172) [76], two caryophyllanes (173 and 174) [76, 81], two elemanes (175 and 176) [76, 79], acorane (177) [76], aristolene (178) [76], bergamotane (179) [81], carabrane (180) [90], cedrane (181) [76], himachalene 
(182) [76], and sesquisabinane (183) [81] as well as 24 other sesquiterpenes (184-203) [72, 75, 76, 78, 79, 81, 92, 94]. Bisabolanes are the most abundant sesquiterpenes in Cur- cuma, and $A r$-turmerone (99) widely occurs in many species of the genus [53].
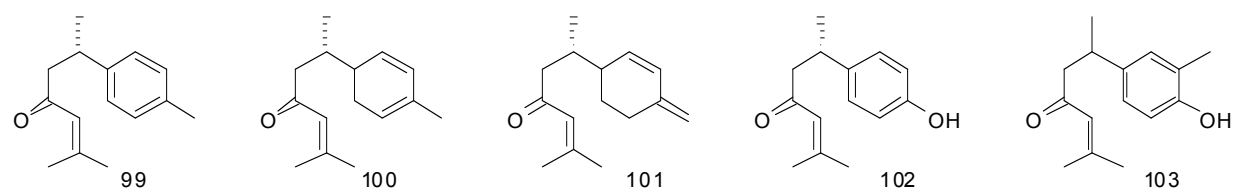<smiles>COC1C=C(C)C(O)CC1C(C)CC(=O)C=C(C)C</smiles><smiles>CC(C)=CC(=O)CC(C)c1ccc(C=O)cc1</smiles><smiles>CC(C)=CC(=O)[C@@H](O)[C@@H](C)c1ccc(C)cc1</smiles><smiles>C=C1C=CC(CC(=O)CC(C)C)CC1O</smiles>

107<smiles>[R]C(C)/C=C(/C)C(C)c1ccc(C)cc1</smiles><smiles>CC1=CCC(C(C)C)C(=O)C1</smiles><smiles>CC1=CC(=O)C([C@@H](C)CC/C=C(/C)[14CH3])CC1</smiles><smiles>CC(C)=CCCC1C=CC(C)(O)C(O)C1</smiles><smiles>[R]C1([2H])C=CC(CCC(=O)C=C(C)C)CC1</smiles><smiles>[Z17]C(C)=CC(=O)C[C@@H](C)c1ccc(C)c(O)c1</smiles><smiles>CC(C)=CC(=O)C[C@@H](C)c1ccc(C)cc1O</smiles><smiles>CC(C)=CCCC(C)C1CCC(C)=CC1=O</smiles><smiles>CC1=CCC(C)CCC=C1</smiles><smiles>CC(C)=CCCC(C)c1ccc(C)c(O)c1</smiles><smiles>COc1cc(CCC(=O)CC(C)C)ccc1O</smiles><smiles>COc1cc(/C=C\C(=O)CC(C)C)ccc1O</smiles><smiles>CC(C)=CC(=O)/C=C(/C)C1CC=C(C)CC1</smiles>

124

125<smiles>CC(C)=CCCC(C)=C1CC=C(C)CC1</smiles>

132<smiles>CC(C)=CCCC(C)C1=CCC(C)CC1</smiles>

129

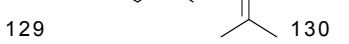<smiles>CC(C)=CCC=C(C)C1CC=C(C)CC1</smiles><smiles>CC(C)=CC(=O)CC(C)=C1CC=C(C)CC1</smiles><smiles>CC(C)=CC(=O)CCC1CCC(C)C(=O)C1</smiles><smiles>CC(C)=CCCC(C)c1ccc(O)cc1O</smiles><smiles>C=C1C=CC([C@@H](C)CC(=O)C=C(C)C#N)CC1</smiles><smiles>CC1=CC(=O)[C@H](C)[C@H](C)CCC2OC2(C)C1</smiles><smiles>C[C@H]1CCCC(C)(O)C1</smiles><smiles>[2H]C1(CC=CC(C)(C)O)CCC(C)=CC1=O</smiles><smiles>CC(C)=CCCC(C)C1CC(O)C(C)CC1O</smiles>

146<smiles>CC(C)=CCCC1CC(C)C=CC1=O</smiles><smiles>C=C(CC(=O)C=C(C)C)[C@H]1CC=C(C)CC1</smiles>

$144 \mathrm{R}=(\mathrm{R})-\mathrm{OH}$
$145 \mathrm{R}=(\mathrm{S})-\mathrm{OH}$

147<smiles>CC(C)=CCC[C@H](C)C1C=CC(C)CC1</smiles><smiles>CC([18F])=CC(=O)CC(C)=C1CC=C(C)CC1</smiles>

137<smiles>CC(C)=CCC[C@H](C)C1(O)CC=C(C)CC1</smiles>

150<smiles>Cc1ccc([C@@H](C)CC(=O)CC(C)C)cc1</smiles>

151<smiles>Cc1ccc(C(C)CCCC(C)C)cc1</smiles>

152<smiles>CC(C)=CC(=O)C1OC2C=C(C)C(O)CC2C1C</smiles> 


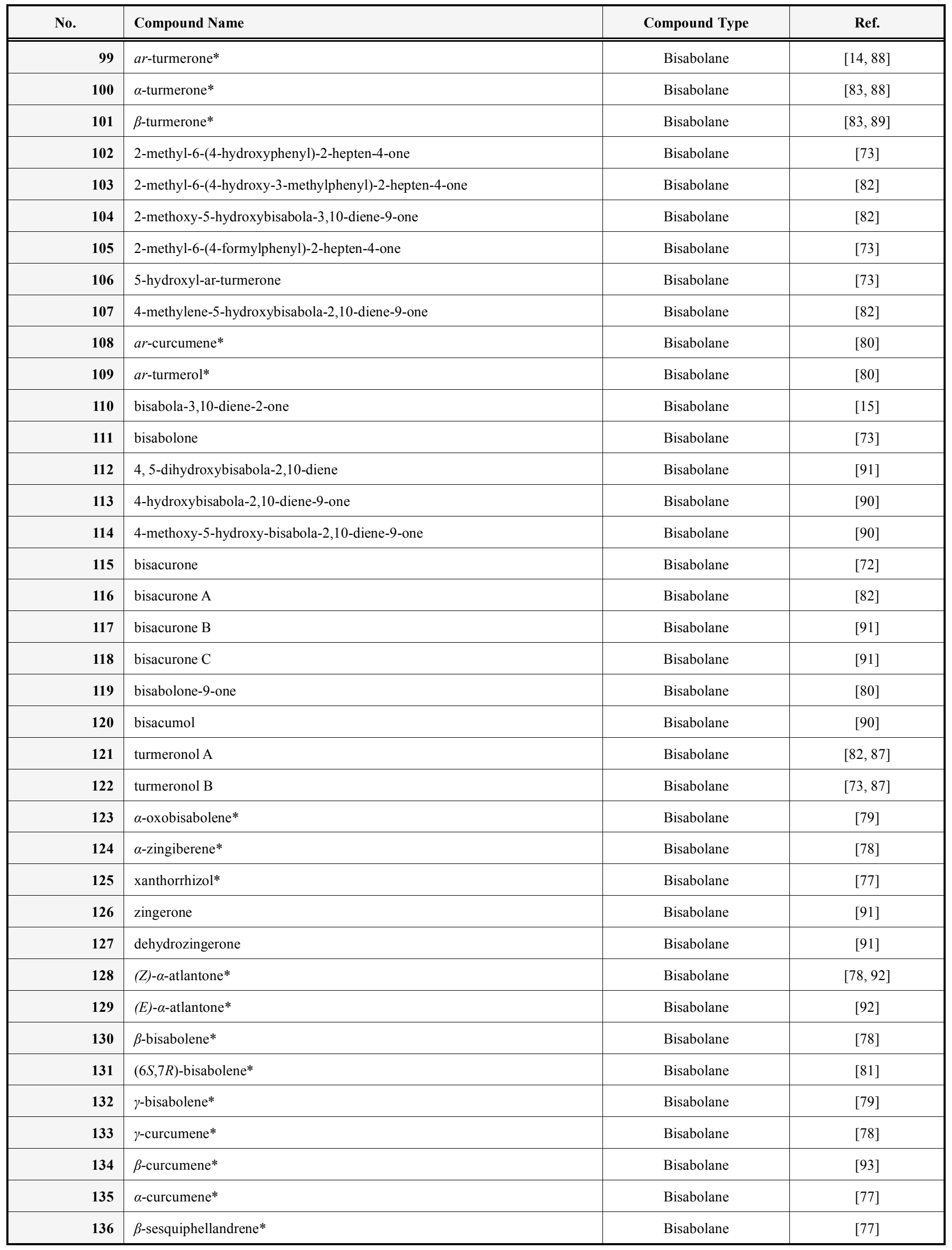




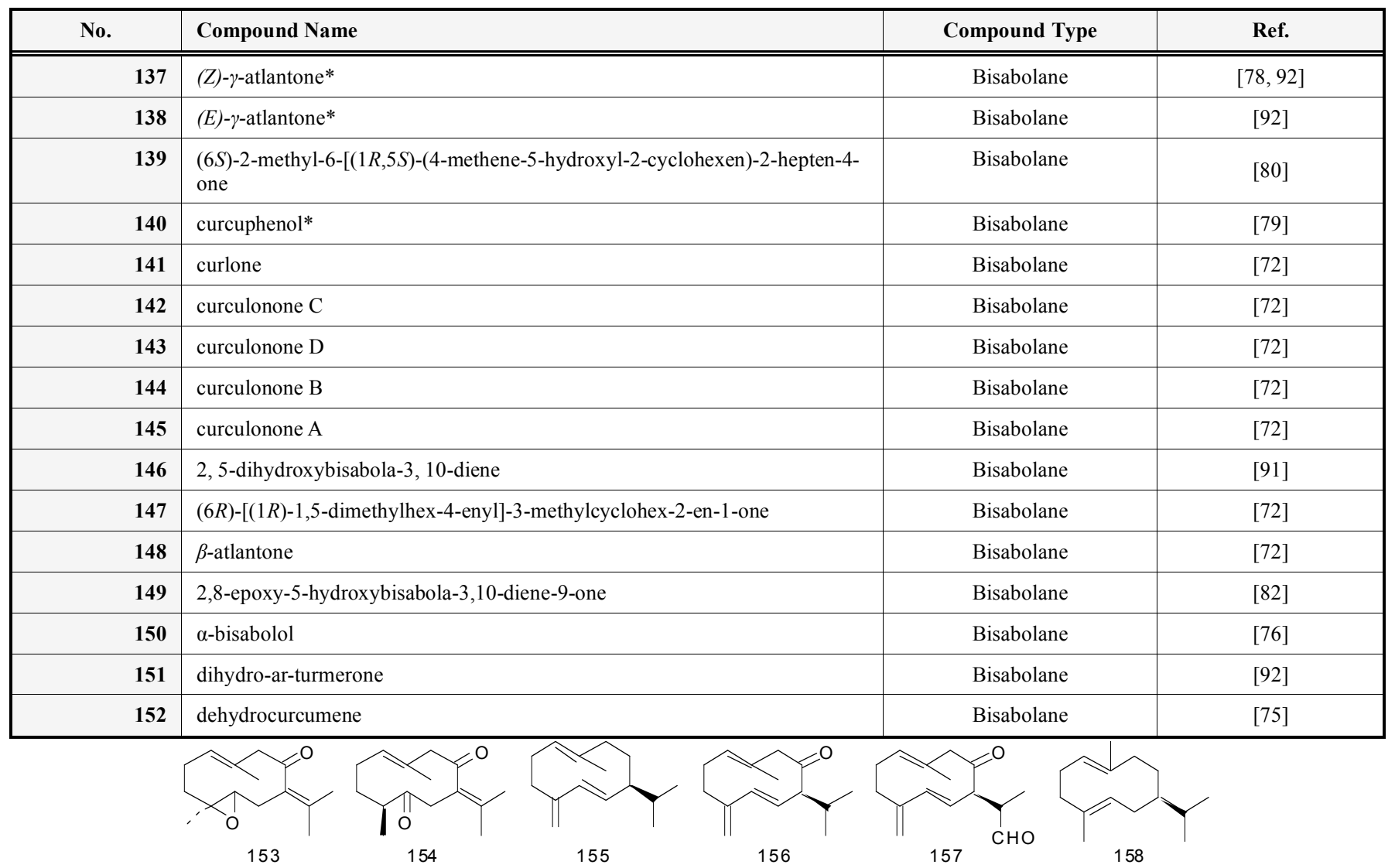<smiles>CC(C)=C1C[C@H]2C(=C(C)C1=O)CC[C@H](O)[C@H]2C</smiles><smiles>CC1=C[C@@]2(O)O[C@@]3(CC2=C(C)C)C1CC[C@H]3C</smiles>

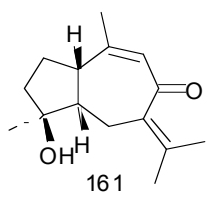<smiles>C=C1CC(=O)C(=C(C)C)CC2(C(O)=P)[C@@H]1CC[C@]2(C)O</smiles>

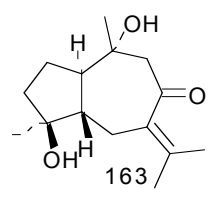<smiles>[R][C@]12CC(=C(C)C)C(=O)C=C(C)[C@@H]1CC[C@]2(C)O</smiles><smiles>CC1=CCC[C@@H]2CCC(=C(C)C)C[C@H]12</smiles>

166<smiles>C=C(C)C1CC[C@@H]2CCC=C(C)C2C1</smiles>

167<smiles>CC(C)=CCCC1(C)C2CCC1(C)CC2</smiles>

171<smiles>C=C[C@H]1CC/C(=C(/C)[18OH])CC1C(=C)C</smiles>

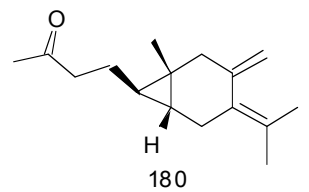<smiles>CC1=CCC2C(C)CCC2C(C)(C)C1</smiles>

181<smiles>C=C1C2CCC(C2)[C@H]1CCC=C(C)C</smiles><smiles>C=C(C)C1CC[C@H](P)C12CC=C(C)CC2</smiles><smiles>C=C1CCCC(C)(C)[C@H]2C=C(C)CC[C@H]12</smiles>

182<smiles>CC(C)=C1CCC2(C)CCCC(C)(O)C2C1</smiles>

168<smiles>C=C(C)C1CCC2(C)C(=O)CCC(C)C2(O)C1</smiles><smiles>C/C=C\CCCC1(C)CCC(C)[C@H]1C</smiles>

173<smiles>CC1CCCC2=CCC3C(C)(C)[C@]3(C)[C@H]21</smiles>

178<smiles>CC(C)=CCC(C)C12CCC(C)(O)C1C2</smiles>

183 


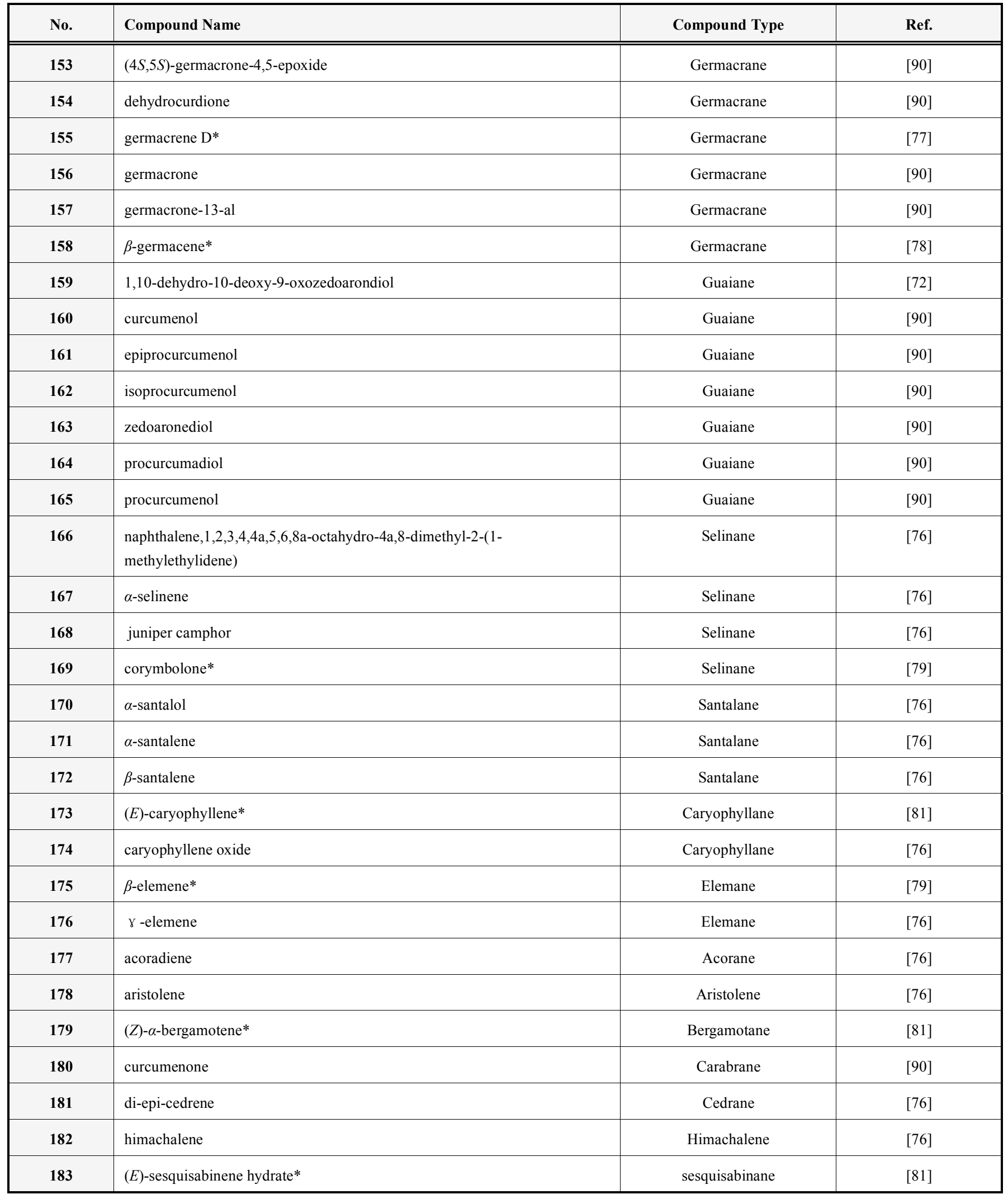


<smiles>C=C1CCCC2C(=C)CC(C)(C)C2CC1</smiles>

184<smiles>C=C(C)[C@@H]1CCCC2CCC(C)C23OC13</smiles>

:<smiles>CC1=C[C@H]2[C@@H](C(C)C)CCC[C@]2(O)CC1</smiles><smiles></smiles><smiles>CC(C)=CCCC(C)C12CC=C(C)C1C2</smiles>

188<smiles>CC(C)=CCCC1(C)CCC=C(C)C1</smiles>

189<smiles>C=C(C)C1CCC(C)(O)C12CC(=C(C)[O-])C(=O)O2</smiles><smiles>C=C(C)C1CCC(C)C12CC(C(C)[18OH])C(=O)O2</smiles><smiles>C=C(C)C1CCC(C)C12CC(=C(C)C)C(=O)O2</smiles>

192

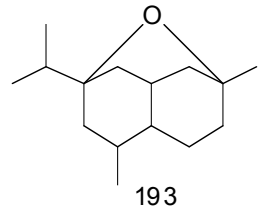<smiles>CC1=CCC/C=C/CC(C)(C)/C=C/C1</smiles>

194<smiles>C/C=C\CC1(C)/C=C\CC2OC2(C)C/C=C/1</smiles>

195<smiles>CC(C)=CCCC(C)CCCC(C)C=O</smiles>

196<smiles>CC(C)=CCC/C(C)=C/CC/C(C)=C/CO</smiles>

197<smiles>C=CC(C)CC/C=C(\C)CCC=C(C)C</smiles><smiles>C=CC(C)(O)CCC=C(C)CCC=C(C)C</smiles>

201

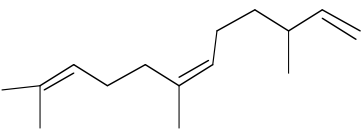

202<smiles>C=CC(C)(CCC=C(C)CCC=C(C)C)OC(=O)CC</smiles>

203

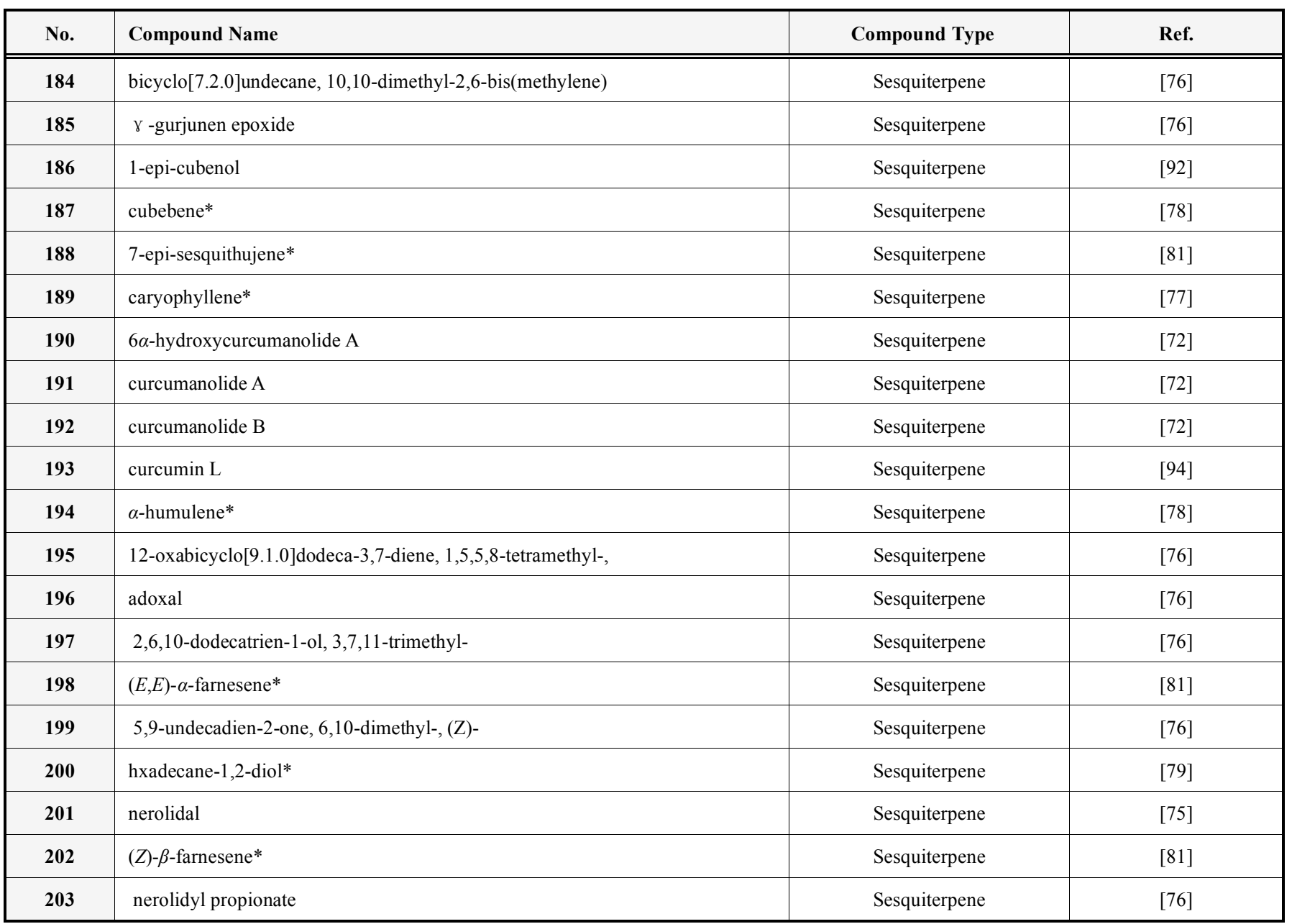


<smiles>C=C/C(C)=C/C/C=C(/C)CC/C=C(\C)CC/C=C(\C)CC/C=C(\C)CCCC(C)/C=C(\C)CCCC(C)CCCC(C)CCCC(C)C</smiles>

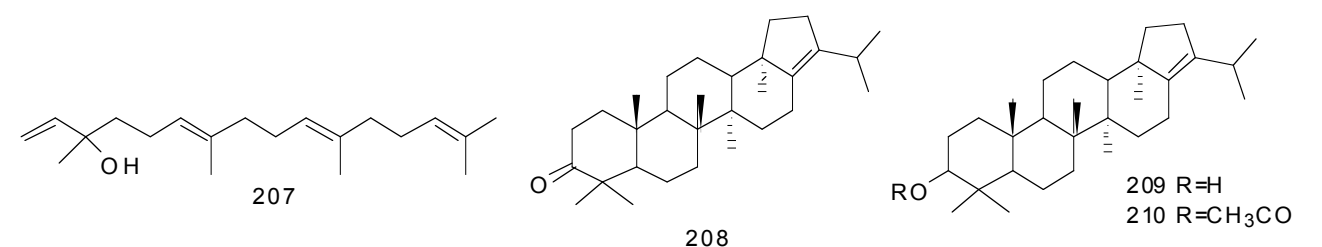

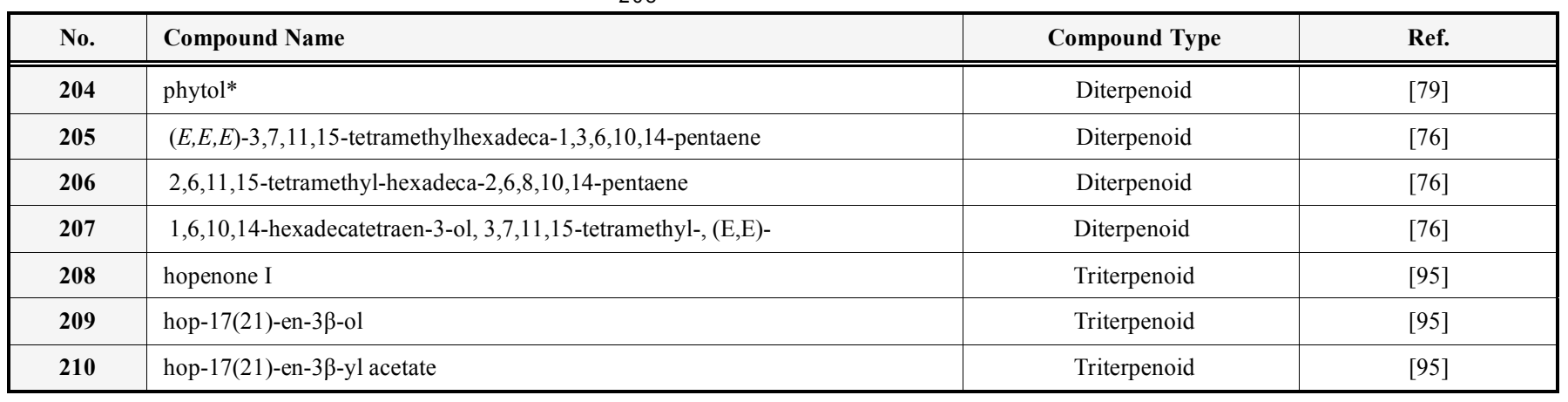

\section{Other Terpenes}

Four diterpenes (204-207) and three triterpenoids (208210) were also identified in turmeric $[76,79,88,95]$.

\section{Steroids}

Four steroids (211-214) were identified from $C$. longa $[72,76]$. But it is questionable that compounds 213 and $\mathbf{2 1 4}$ are present in $C$. longa.

\section{Fatty Acids}

Following are five long chain fatty acids (215-219) identified from C. longa [72, 76].

\section{Miscellaneous}

There are 16 other compounds (220-235) found in $C$. longa $[76,91,96]$.
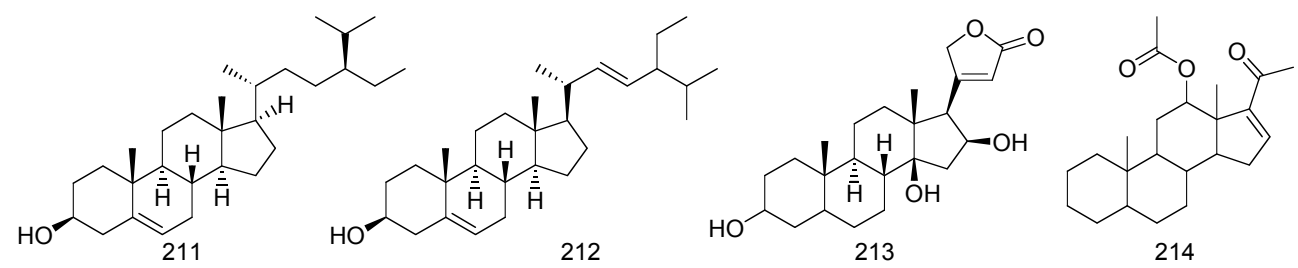

\begin{tabular}{|c|l|c|c|}
\hline No. & Compound Name & Compound Type & Ref. \\
\hline \hline $\mathbf{2 1 1}$ & $\beta$-sitosterol & Steroid & Steroid \\
\hline $\mathbf{2 1 2}$ & stigmasterol & Steroid & {$[72]$} \\
\hline $\mathbf{2 1 3}$ & gitoxigenin & Steroid & {$[72]$} \\
\hline $\mathbf{2 1 4}$ & 20-oxopregn-16-en-12-yl acetate & {$[76]$} & \\
\hline
\end{tabular}<smiles>CCCCCCCCCCCCCCCCCCCCC(=O)O</smiles>

218

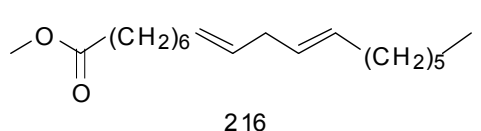

216<smiles>CCCCCCCCCCCCC(=O)O</smiles>

219 


\begin{tabular}{|c|l|c|c|}
\hline No. & Compound Name & Compound Type & Fatty acid \\
\hline \hline $\mathbf{2 1 5}$ & linoleic acid* & Fatty acid & {$[79]$} \\
\hline $\mathbf{2 1 6}$ & 8,11 -Octadecadienoic acid, methyl ester* & Fatty acid & {$[79]$} \\
\hline $\mathbf{2 1 7}$ & palmitic acid (n-hexadecanoic acid)* & Fatty acid & {$[79]$} \\
\hline $\mathbf{2 1 8}$ & oleic acid* & Fatty acid & {$[79]$} \\
\hline $\mathbf{2 1 9}$ & stearic acid* & {$[79]$} \\
\hline
\end{tabular}

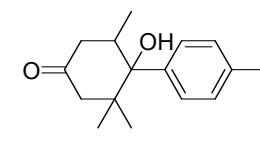<smiles>Cc1cc2c(C)cc(CC(C)C)nc2cc1O</smiles><smiles>CC1=C(C)C(C)(CO)CC1</smiles><smiles>Cc1ccc(CCC2CCCC2)c(C)c1</smiles><smiles>Cc1ccc(C)c(CC(C)C)c1</smiles>

222 26<smiles>CC1C2CC(O)OC2C2CCC1C2(C)C</smiles>

227<smiles>CC1C([13CH3])C2CCCC(C2=O)C1[N+](=O)[O-]</smiles><smiles>CC(C)(C)OOC(C)(C)c1ccccc1</smiles><smiles>CC(=O)OC1CC(C)CC(C)(C)C1</smiles>

230<smiles>CC1C(=O)C2C3C=CC(O3)C1C2C</smiles>

231<smiles>CCC(C)=CCCC1(C)CCC=C(C)C1C</smiles>

232

228

229

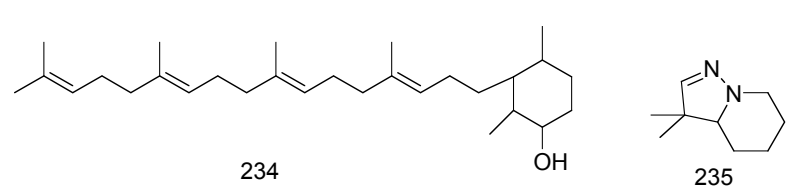

\begin{tabular}{|c|c|c|}
\hline No. & Compound Name & Ref. \\
\hline 221 & 2-(2'-methyl-1'-propenyl)-4, 6-dimethyl-7-hydroxyquinoline & [91] \\
\hline 222 & 2,3,5-trimethylfuran & {$[76]$} \\
\hline 223 & (1,2,3-trimethyl-cyclopent-2-enyl)-methanol & {$[76]$} \\
\hline 225 & 1-(3-cyclopentylpropyl)-2,4-dimethy-benzene, & [76] \\
\hline 226 & 1,4-dimethyl-2-(2-methylpropyl)-benzene & [76] \\
\hline 227 & 2,2'-oxybis[octahydro-7,8,8-trimethyl-4,7-methanobenzofuran & {$[76]$} \\
\hline 228 & cyclohexyl formate & {$[76]$} \\
\hline 232 & 2,6-dimethyl-6-(4-methyl-3-pentenyl)-2-cyclohexene-1-carboxaldehyde & {$[76]$} \\
\hline 233 & bicyclo[3.3.1]nonan-9-one, 2,4-dimethyl-3-nitro- (exo)- & {$[76]$} \\
\hline 234 & 2,2,4-trimethyl-3-(3,8,12,16-tetramethyl-heptadeca-3,7,11,15-tetraenyl)-cyclohexanol & [76] \\
\hline 235 & pyrazolo[1,5-a]pyridine, 3,3a,4,7-tetrahydro-3,3-dimethyl-, (3aS) & [76] \\
\hline
\end{tabular}

\section{ACTIVE INGREDIENTS}

\section{Variations of Curcuminoids}

Curcuminoids in turmeric are primarily accumulated in rhizomes of turmeric [97]. The contents of curcuminoids in turmeric rhizomes vary often with varieties, locations, sources, and cultivation conditions [2, 8, 97-100] (Table 2). Ratnambak et al. reported curcumin (1) varied from $2.8 \%$ to $10.9 \%$ among the 120 cultivars or accessions of C. longa from all over India and $0.02 \%$ to $8.0 \%$ among the 64 culti- 
vars or accessions of related species [50]. It was found that there are significant variations in curcumin (1) (0.61 to $1.45 \%$ on a dry weight basis) in turmeric rhizomes in its native North Indian plains [101]. Curcumin (1) contents of turmeric rhizomes in Thailand range from 1.28 to $6.6 \%$ (on a dry weight basis) [6]. Curcumin (1) contents in commercial turmeric powders vary from 0.58 to $3.14 \%$ (on a dry weight basis) [102]. It was also reported the total curcuminoids content of rhizomes from 66 locations in Thailand varies from 0.46 to $10.23 \%$ (on a dry weight basis) [103]. Turmeric crop cultivars in India have been classified as either high or low curcumin (1) varieties (e.g., 'Alleppey' having 5.5\% curcumin (1)) as well as short, medium or long duration [2, 50, 104].

Plant maturity has significant impact on chemical constituents of turmeric rhizomes of Curcuma. In Sri Lanka, both total curcuminoids and curcumin (1) in rhizome reach the highest yield at 5.5 months and maturity results in decline of these pigments but essential oils will not reach maximum yield until 7.5 to 8 months [84]. Similarly, it was found the rhizomes of five-month old plants yield the highest contents of both total curcuminoids and curcumin (1) and contents declined from five to ten month-old plants in Thailand [7]. In Japan, it was reported that curcumin (1) content of primary rhizome increased from September to October [97]. However, there is no significant change in the content of curcuminoids was observed during the growing season from October to February [105]. In general, curcumin (1) content in mother rhizome is higher than in finger rhizomes $[98,106]$. The composition of both curcuminoids and essential oils of the turmeric rhizomes from in vitro propagated plants had no significant difference from those in traditionally propagated plants [79].

Plants grow in different habitats may also affect curcumin (1) yield in rhizomes. It was found that turmeric grown in the South of Thailand with rainfall all year contained higher levels of total and individual curcuminoids [107]. A recent Japanese study showed that curcumin (1) content in rhizomes from the plants cultivated in dark-red soil is about $100 \%$ higher than in those from gray soil and more than $200 \%$ high than those from red soil [108]. It was also reported that potassium in soil positively affect curcumin (1) yield in rhizomes [109]. Post harvest processing of turmeric is also an important factor to affect the content of curcuminoids. However, some reports are controversial, for example, one study found that concentration of curcumin (1) was reduced by by $27-53 \%$ from heat processing of turmeric (e.g., curing with boiling water) [110], but another investigation indicated that heat treatment of turmeric prior to dehydration increased curcuminoid levels [111].

There are a few physiological investigations in plant growth and development of turmeric [112] [113-116]. Also, significant variations of curcumin contents were observed in different varieties, locations, growth stages, and environments (Table 2). It is believed that curcumin is produced in leaves and is then translocated to rhizome [117]. However, the mechanism of metabolism and accumulation of curcuminoids remain elusive and induced production of the active ingredients has not been addressed.

\section{Variations of Essential Oils}

There are significant variations in both content level and constituents of essential oils of turmeric rhizomes with geographical locations (Table 3). Among the 27 accessions North Indian plains at Lucknow, India, the percentage essential oil content in the fresh rhizomes varied between $0.16 \%$ and $1.94 \%$ (on a fresh weight basis) [101]. Although usually sesquiterpenes, particularly $A r$-turmerone (99), $\alpha$-turmerone (100) [83], and $\beta$-turmerone (101) are major compounds in turmeric oils in Asia, presence of other compounds in $C$. longa often vary with various locations. By using GC-MS analysis, Chowdhury and his coworkers identified 54 compounds of essential oils from the "yellow type" of C. longa while only 39 compounds were detected from the "red type" growing in Bangladesh [76]. The essential oil in "yellow type" were dominated by ar-tumorone (99) (27.78\%), turmerones (100 and 101) (17.16\%), curlone (141) $(13.82 \%)$, 2-carene (73) (4.78\%), zingiberene (124) (4.37\%) and $\beta$ sesquiphellandrene (136) (5.57\%), but the "red type" oil mainly contained carvacrol (43) $(21.14 \%)$, citral $(13.91 \%)$, methyleugenol (229) (7.31\%), geraniol (86) (6.99\%), menthol (46) (5.11\%) and caryophyllene oxide (168) $(4.14 \%)$ [76]. However, there is no significant difference was observed in essential oil composition between T3C turmeric and Hawaiian red turmeric [79]. Unlike those from Asia, interestingly, turmeric oils from Brazil contained $50-80 \%$ of ar-turmerone (99), $(Z)-\gamma$-atlantone (137), and $(E)$ - $\gamma$-atlantone (138) $[81,92] .(Z)-\gamma$-atlantone (137) and $(E)$ - $\gamma$-atlantone (138) are only found in the turmeric from Brazil. Without information of which cultivars or varieties were used in these studies, however, it is impossible to determine the difference caused by geographical or genetic variation. Constituent of essential oil varies with different species of Curcuma [119125]. For example, $\alpha$-curcumene, a minor compound in $C$. longa, is the major constituent (approx. 65\%) of the essential oil of Javanese turmeric (C. xanthorrhiza) [46].

\section{Stability of Active Ingredients}

In addition to their significant variations with geographic locations and genotypes, both curcuminoids and essential oils are unstable under different extraction and storage conditions.

Curcumin (1) is absorbed poorly by the gastrointestinal tract and/or undergoes presystematic transformation $[133,134]$. As a natural coloring agent, it is known to be unstable particularly under alkaline conditions, light, and high temperature [135-137]. Curcumin (1) rapidly decomposes into trans-6-(4,-hydroxy-3,-methoxyphenyl)2,4-dioxo-5-hexenal, vanillion, ferulic acid, and feruloymethane at condition of $\mathrm{pH}>7.0[134,138,139]$. For example, approximately $90 \%$ of curcumin (1) decomposed when it was incubated in $0.1 \mathrm{M}$ phosphate buffer and serum-free medium, $\mathrm{pH} 7.2$ at $37^{\circ} \mathrm{C}$ for $30 \mathrm{~min}$ [134]. Halflife period $\mathrm{T}_{1 / 2}$ of curcumin (1) is about $26.2 \mathrm{~h}$ at $\mathrm{pH} 9.0 \mathrm{in}$ comparison of $501.5 \mathrm{~h}$ at $\mathrm{pH} 6.0$ [138]. In another report, more than $90 \%$ of curcuminoids (composition of curcumin (1), demethoxycurcumin (2), and bisdemethoxycurcumin (5)) were decomposed within $12 \mathrm{~h}$ when serum was omitted [56]. All curcuminoids are stable when they 
Table 2. Content Variations of Curcuminoid Contents in Different Varieties, Locations, Products, or Extracts of Turmeric (C. longa)

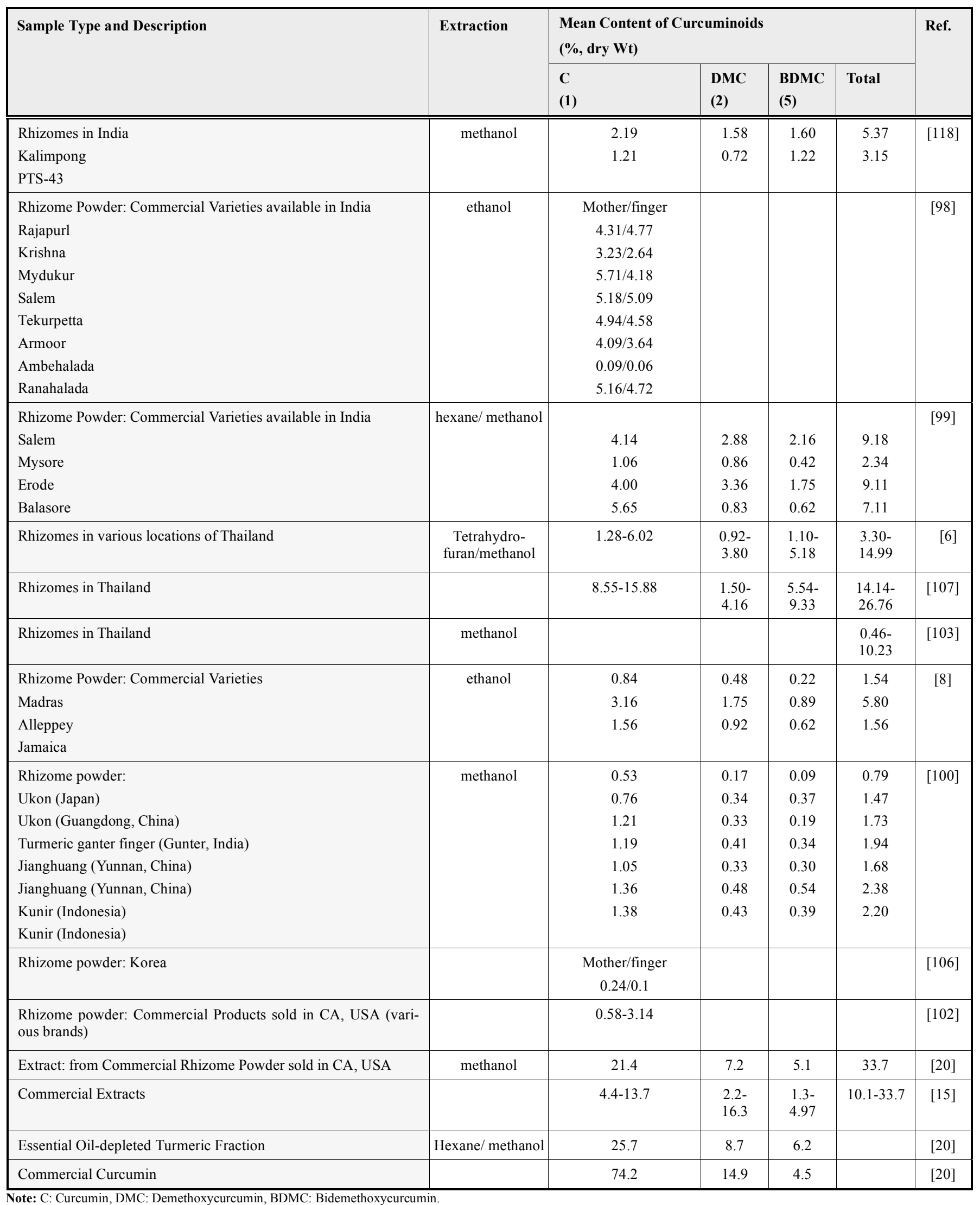


Table 3. Variations of major monoterpenes and sesquiterpenes in the essential oil of turmeric $(C$. longa) and its related taxa

\begin{tabular}{|c|c|c|c|c|c|c|c|c|c|c|c|c|c|c|c|c|c|c|c|c|c|c|c|c|c|c|c|c|c|c|}
\hline & \multicolumn{12}{|c|}{ Monoterpenes } & \multicolumn{17}{|c|}{ Sesquiterpenes } & \\
\hline & 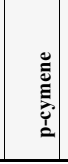 & 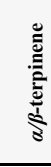 & 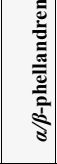 & 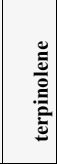 & 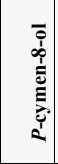 & ) & 产 & 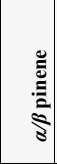 & $\frac{0}{\circ}$ & 氖 & $\begin{array}{l}\overline{\bar{o}} \\
\frac{\bar{g}}{\tilde{g}} \\
\stackrel{\Xi}{=}\end{array}$ & 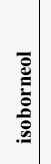 & 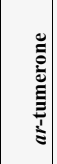 & 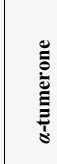 & 竞 & 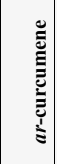 & | & 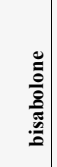 & 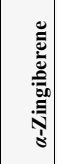 & 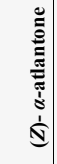 & 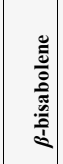 & 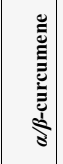 & 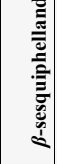 & 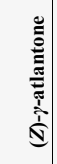 & 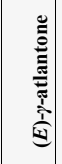 & 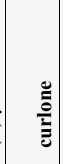 & | & : & 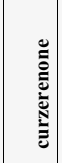 & \\
\hline & 31 & $\begin{array}{l}33 / \\
34\end{array}$ & 35 & 40 & 55 & 61 & 71 & $\begin{array}{l}75 / \\
76\end{array}$ & 77 & 82 & 89 & & 99 & 100 & 101 & 108 & 105 & 111 & 124 & 128 & 130 & $\begin{array}{l}135 / \\
134\end{array}$ & 136 & 133 & 134 & 141 & 156 & 202 & 139 & \\
\hline $\begin{array}{l}\text { Leaves, India } \\
\text { (HD) }\end{array}$ & 5.9 & 2.8 & 35.8 & 26.0 & & & & 4.9 & 6.5 & 2.3 & 0.7 & & & 0 & .9 & & & & & & & & & & & & & & & [75] \\
\hline $\begin{array}{l}\text { Leaves, India } \\
\text { (HD) }\end{array}$ & 5.5 & 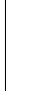 & 9.1 & 8.8 & 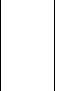 & 7.3 & & 0.3 & & 1.6 & & & & & & & & & & & & & & & & & & & & [93] \\
\hline $\begin{array}{l}\text { Leaves, } \\
\text { Bhutan } \\
\text { (HD) }\end{array}$ & 13.3 & 1.0 & 18.2 & 11.6 & 2.4 & 14.6 & & 9.8 & & 1.8 & 1.2 & & & & & & & & & & & & & & & & & & & [93] \\
\hline $\begin{array}{l}\text { Rhizome, } \\
\text { India } \\
\text { (HD) }\end{array}$ & 1.8 & & & & & & & 9.2 & & & & & 25.4 & 11.9 & 8.3 & & & & & & & 3.9 & & & & & & & & [101] \\
\hline $\begin{array}{l}\text { Rhizome, } \\
\text { India } \\
\text { (HD) }\end{array}$ & 3.0 & & 3.0 & & & & & & & & & & 31.1 & 10 & 0.0 & 6.3 & & 0.9 & $\operatorname{tr}$ & & 1.3 & & 2.6 & & & 10.6 & & & & [75] \\
\hline $\begin{array}{l}\text { Rhizome, } \\
\text { India } \\
\text { (HD) rhizome }\end{array}$ & & & 0.1 & & & & & & 2.6 & & & & 31.7 & 12.9 & 12.0 & & 0.1 & & 1.3 & 1.5 & & 1.3 & & & & & & & & [93] \\
\hline $\begin{array}{l}\text { Rhizome, } \\
\text { Bhutan } \\
\text { (HD) }\end{array}$ & & & 1.1 & & & & & & 0.9 & & & & 25.7 & 32.0 & 18.4 & & 1.3 & & 1.5 & 1.1 & & 1.4 & & & & & & & & [93] \\
\hline $\begin{array}{l}\text { CRTO, India } \\
\text { (hexane) }\end{array}$ & & & & & & & & & & & & & 62.0 & 5 & .1 & 3.5 & 0.9 & & 2.5 & & 2.1 & & & & & 3.9 & & 6.6 & & [42] \\
\hline CRTO, India & & & & & & & & & & & & & 31.3 & 15 & 5.1 & 6.2 & & & 3.2 & & 0.8 & & & & & 9.7 & & 3.2 & & [126] \\
\hline $\begin{array}{l}\text { Rhizome, } \\
\text { India }\end{array}$ & & & & & & & & & & & & & 51.8 & & & & 11.9 & & & & & & & & & & & & & {$[40]$} \\
\hline $\begin{array}{l}\text { Rhizome, } \\
\text { China }\end{array}$ & & & & & & & & & & & & & 18 & 2 & 4 & & & & & & & & & & & & & & & [127] \\
\hline $\begin{array}{l}\text { Rhizome, } \\
\text { Bangladesh } \\
\text { (yellow type) }\end{array}$ & 0.7 & & & & & & & & & & & & 27.8 & 17 & 7.2 & 3.3 & & 2.0 & 4.4 & & 2.9 & & 5.6 & & & 13.9 & & & & {$[76]$} \\
\hline $\begin{array}{l}\text { Rhizome, } \\
\text { Bhutan }\end{array}$ & & & & & & & & & & & & & $\begin{array}{l}16.7 \\
- \\
25.7\end{array}$ & \begin{tabular}{|l|}
30.1 \\
- \\
32.0
\end{tabular} & \begin{tabular}{|l|}
14.7 \\
- \\
18.4
\end{tabular} \mid & & & & & & & & & & & & & & & [86] \\
\hline Rhizome, Iran & & & & & & & & & & & & & 68.9 & 20.9 & & & & & 1.5 & & 0.4 & & 1.3 & & & & & & & [128] \\
\hline $\begin{array}{l}\text { Rhizome, } \\
\text { French } \\
\text { Polynesia }\end{array}$ & & & & & & & & & & & & & 15.5 & & & & & & 16.7 & & & & & & & & & & & [129] \\
\hline
\end{tabular}


Table 3. Contd....

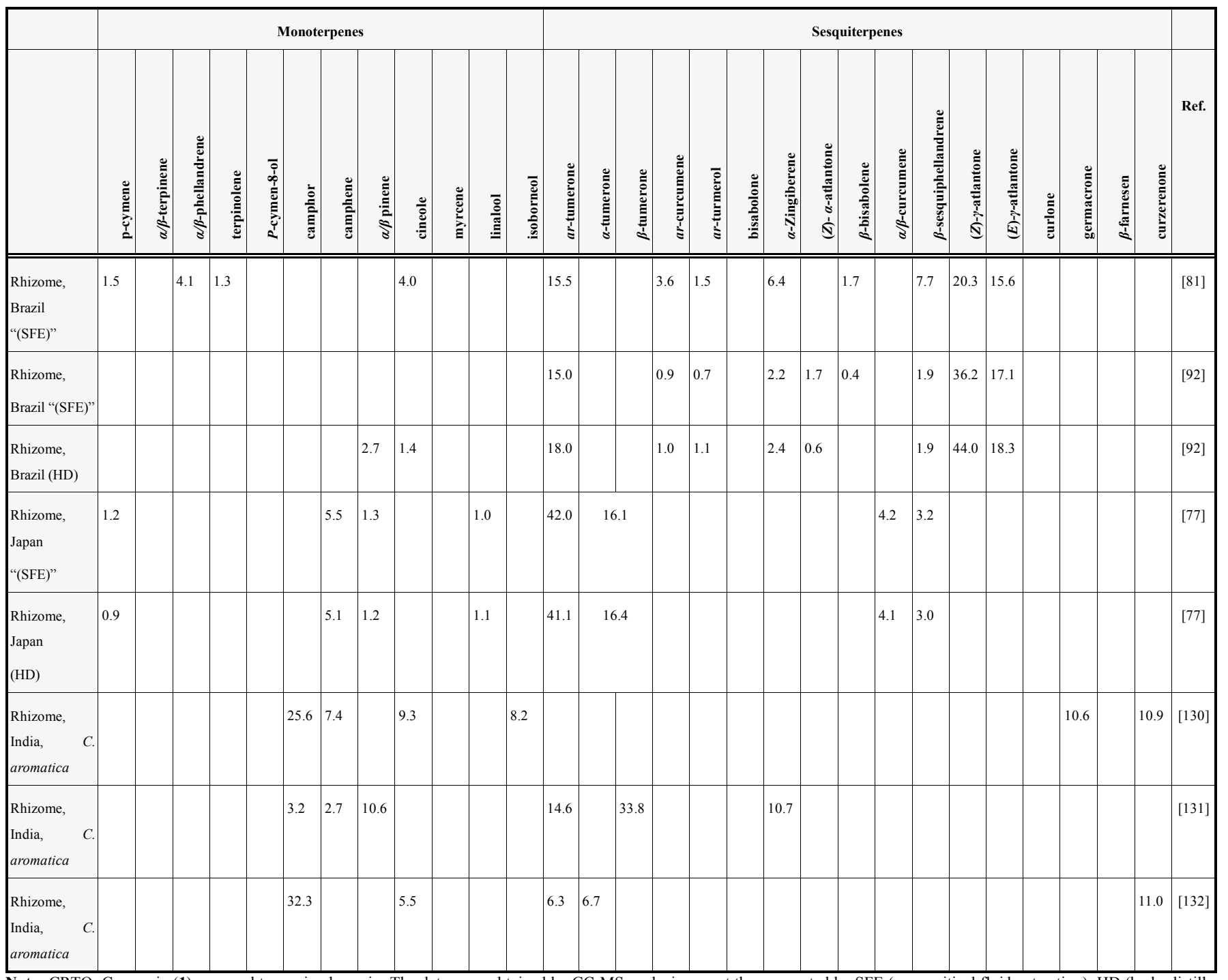

Note: CRTO: Curcumin (1) removed turmeric oleoresin; The data were obtained by GC-MS analysis except those as noted by SFE (supercritical fluid extraction), HD (hydrodistillation), or Soxhlet extraction. tr: trace.

are kept under minimum light condition [140]. In methanol sparged with air, stability to photooxidation was curcumin (1) > demethoxycurcumin (2) > bisdemethoxycurcumin (5) [140]. It was found that the stability of curcumin (1) in aqueous solution is strongly increased by the presence of some antioxidants [141]. But the presence of other curcuminoids (II and III) which are antioxidants seem not prevent degradation of curcumin (1) [56].

\section{Extraction Methods}

Extraction rate and composition of curcuminoids and essential oils are significantly affected by various extraction techniques such as hydrodistillation, low pressure solvent extraction, Soxhlet, and supercritical fluid extraction (SFE) using carbon dioxide, with different coextraction solvents [92]. The largest yield (27\%, weight) was obtained in the Soxhlet extraction with ethanol; the lowest yield was detected in the hydrodistillation process $(2.1 \%)$. For SFE, the best cosolvent was a mixture of ethanol and isopropyl alcohol [92]. Although SFE and hydrodistillation processes may produce different yields of total oils, but the percentage of their major compounds extracted by these two methods are similar [77, 92].

Isolation of pure curcumin (1) from turmeric is difficult and time-consuming, and thus the commercial "pure" curcumin (1) is in fact a mixture of at least three curcuminoids. Such curcuminoids can decompose rapidly, but curcuminoids in both turmeric powder and extracts are more stable [138]. Among different extraction solvents, ethanol extraction gives the highest yield of curcuminoids $[92,142]$. In comparison to hexane extraction which yields sesquiterpenoids only, ethanol extraction yields both curcuminoids and sesquiterpenoids. It was found that curcuminoids and sesquiterpenoids together have synergistic effect on their bioactivities [89]. Our preliminary study showed that $70 \%$ ethanol is better than water (boiling or at room temperature), $30 \%, 50 \%$ ethanol in extraction of three curcuminoids. It was reported that ethanol 
Table 4. Contents of Active Ingredients in the Plant Samples and Extracts of Different Batches

\begin{tabular}{|l|c|c|c|}
\hline Sample/Active Ingredients & $\begin{array}{c}\text { Rhizome Powder (Mean) } \\
\text { (\%, Dry wt) }\end{array}$ & $\begin{array}{c}\text { Extracts } \\
\text { (Mean } \pm \text { s.d.) } \\
\text { (\%, Dry wt) }\end{array}$ & Yield of Extracts (\%) \\
\hline \hline Curcumin & 2.86 & $19.51 \pm 2.07$ & $10-13$ \\
Demethoxycurcumin & 1.47 & $8.31 \pm 1.13$ & \\
Bidemethoxycurcumin & 1.36 & $6.22 \pm 0.88$ & \\
Total Curcuminoids & 5.69 & $34.04 \pm 4.08$ & \\
\hline
\end{tabular}

Note: authors' unpublished data.

extract, particularly high grade ethanol extract is more stable (e.g., $80 \%$ ethanol $>$ acetone $>60 \%$ ethanol, $>50 \%$ ethanol or ethyl ether $>$ ethyl acetate $>40 \%$ ethanol $>$ petroleum ether or water or pure curcumin (1)) [138]. Thus, ethanol not only can produce effective extraction of curcumnoids but also the curcuminoids in ethanol extract can be less decomposed than the three curcuminoids combined.

Recently, we have used the following extraction method of curcuminoids in our research projects. Ground plant powders of turmeric (Sami Labs Limited, moisture content $5 \%, \sim 60$ mesh) were extracted separately with $70 \%$ ethanol at room temperature for $18 \mathrm{~h}$ (solvent volume/material weight, 10:1) for three times. After vacuum filtration, the combined ethanol extracts of each sample were concentrated under reduced pressure with rotary evaporator. The residues were then transferred to $40 \mathrm{~mL}$ vials and further evaporated with speed vacuum at $\sim 45^{\circ} \mathrm{C}$ for $48 \mathrm{~h}$. Authentic compounds, curcumin (1) (94\%) were purchased from Sigma-Aldrich and re-purified in our study. These three curcumnioids were analyzed and quantified by HPLC method that was carried out on Agilent 1100 instrument with Agilent Zorbax SB-C18 column $(4.6 \times 250 \mathrm{~mm}, 5 \mu \mathrm{m})$ and linear gradient of $30 \%$ acetonitrile to $70 \%$ acetonitrile in $45 \mathrm{~min}$ then increase to $90 \%$ by $65 \mathrm{~min}$. The flow rate was $0.7 \mathrm{~mL} / \mathrm{min}$ with detection wavelength at 230 and $425 \mathrm{~nm}$. The sample description and analysis result of active ingredients of the plant samples and experimental extracts are summarized in Table 4.

\section{QUALITY AND STANDARDIZATION OF TUR- MERIC PRODUCTS}

\section{Marker Compounds}

Because of variations of active ingredients with seed sources, habitats, plant age, harvest and dry process, commercial turmeric rhizomes and products have significant variations in curcumin (1) contents $(0.58$ to $6.5 \%$ on a dry weight basis) (Table 2). Also, curcuminoids could rapidly decompose under certain storage conditions. The chemical variability will result in inconsistent results and uncertain efficacy in experiments and clinical trials. Thus, there is need for standardization of chemical ingredients in turmeric products.

According to the Indian Pharmacopoeia (1996), dried turmeric rhizomes should contain not less than $1.5 \%$ of curcumin (1) (w/w). The Pharmacopoeia of People's Republic of China (2005) requires no less than $1.0 \%$ of curcumin (1) content $(\mathrm{w} / \mathrm{w})$ in dried turmeric rhizomes [5]. The Thai Herbal Pharmacopoeia recommended that dried turmeric should contain no less than $6 \%$ of turmeric oil $(\mathrm{v} / \mathrm{w})$ and $5 \%$ of total curcuminoids (w/w) [103]. WHO (World Health Organization) suggests that not less than $4.0 \%$ of volatile oil, and not less than $3.0 \%$ of curcuminoids in turmeric [9]. In our initial investigations for chemoprevention of colorectal cancer, we required that the rhizomes contain no less than $5 \%$ of total contents of three bioactive curcuminiods and the experimental rhizome extracts contain no less than $25 \%$ of the three curcuminoids (Aggarwal et al., unpublished data).

As a number of studies have suggested that ethanol extract showed better extraction efficiency and stability of active curcuminoids, the ethanol was selected as a solvent for turmeric extraction. Each turmeric samples were labeled with individual code and extract with $95 \%$ ethanol by Dionex ASE 200 Accelerated Solvent Extractor. The chemical profiles of each product were characterized by defining and verifying the curcumin (1), demethoxycurcumin (2), and bisdemethoxycurcumin (5) and determining its concentrations by HPLC (Fig. 2). The HPLC chromatogram with UV/VIS detection at $425 \mathrm{~nm}$ provided an important basis for product quality control. The minimum $5 \%(\mathrm{w} / \mathrm{w})$ of three major curcuminoids $(\mathbf{1}, \mathbf{2}$, and $\mathbf{5})$ in the turmeric extract were determined based on the initial activity data with consideration of the requirements for the turmeric rhizomes from above Pharmacopoeias.

Turmeric oils and oleoresins have shown various promising activities and have been marketed globally. The major ketonic sesquiterpenes, particularly, $A r$-turmerone (99), $\alpha$ turmerone (100), and $\beta$-turmerone (101) have been used to control the product quality, e.g., minimum $40 \%$ of these marker compounds in turmeric oils and oleoresins produced by hydrodistillation (see Table 3). Turmeric oils and oleoresins produced by SFE (supercritical fluid extraction) usually have lower yield of these compounds, and may use $\mathrm{Ar}$ turmerone (99), $(Z)$ - $\gamma$-atlantone (133), and $(E)$ - $\gamma$-atlantone (134) to control the quality of these particular products (e.g., $>50 \%$ of these three compounds). 


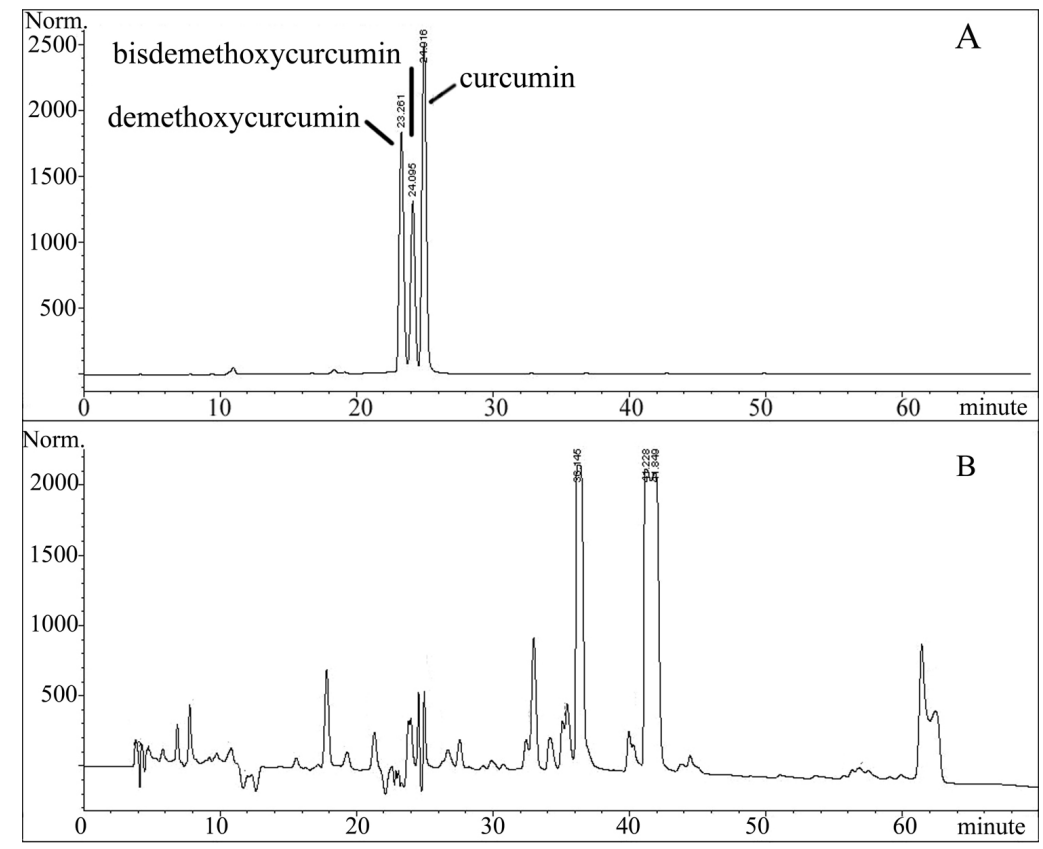

Fig. (2). HPLC chromtograms of ethanol extracts of "Ground Tumeric" (A detected at $425 \mathrm{~nm}$ and B detected at $230 \mathrm{~nm}$, respectively). The samples were extracted by ASE-200 and analyzed by HPLC (Agilent 1100) (Column: SB-C18; 30\% acetonitrile to 70\% acetonitrile in 45 min, increase to $90 \%$ by $65 \mathrm{~min}$; flow rate, $0.7 \mathrm{~mL} / \mathrm{min}$ ).

\section{Adulteration}

Though whole dried or fresh turmeric are usually free from adulteration, turmeric powder can be adulterated with powders of certain other species of Curcuma [143]. Usually, adulterated products of ground turmeric have low content of curcuminoids and are even toxic when C. zedoaria, a common adulterant is included in turmeric powder [144]. Morphologically, the rhizomes of the two species can be distinguished by nature and color (highly branched and yellow rhizomes of $C$. longa vs. less branched bulbous and orange yellow rhizomes of $C$. zedoaria) or oil cell sizes (small in $C$. longa vs. large in C. zedoaria) [145]. Occasionally, other Curcuma species such as $C$. aromatica (C. wenyujin) may be used to substitute $C$. longa for turmeric production. $C$. aromatica can be identified by its less branched and creamy rhizomes with less primary vascular bundles and few curcumin cells [145]. The identity of questionable samples of turmeric powders can be examined under light or/and scanning electronic microscope in comparison with authentic samples and referencing with literatures. Comparative rhizome anatomy and microscopic characters of C. longa and related species are reported $[51,145,146]$.

DNA markers can also be useful in identification of some species of Curcuma. For example, ISSR (inter simple sequence repeats) and RAPD (random amplified polymorphic DNA) markers were developed for 15 species of Curcuma from India [147]. Based on trnK gene sequences, a rapid LAMP (loop-mediated isothermal amplification) method was developed to identify C. longa and C. aromatica [148]. More recently, method for identification of these species and C. zedoaria as well as C. xanthorrhiza was reported by determining DNA polymorphisms in the trnS-trnfM intergenic spacer in chloroplast DNA [149]. It was found DNA sequence characterized amplified region (SCAR) markers can be useful in detection of Curcuma hybrids [150].

Only few species of the genus Curcuma have ever been phytochemically investigated and the chemical compositions are markedly varied among these species [53, 151-156]. Thus chemical fingerprints of curcuminoids or essential oils of each species became necessary and served as identification markers. Chemical analysis will provide useful information for any questionable samples of dried rhizomes, ground turmeric, turmeric oils or oleoresins, and curcuminoids/cucumin. For turmeric extracts or isolates, chemical fingerprints appear to be the only approach to determine the product quality. Chemical analysis becomes particularly necessary when exotic chemicals (either natural or synthetic compounds) adulterants in turmeric, e.g., dyes such as Sudan dyes [157-159]. Chromatographic techniques (HPLC, HPLC-ESI-MS, LC-MS, GC-MS, CE) [99, 105, 152, 154156, 160-166], UV spectrophotometry [107, 158, 159], Xray crystallography $[157,159]$, or NMR spectroscopic analysis have been used as powerful tools for identification of the quality of product in various studies. In contrast, thin layer chromatography may not be helpful in identifying adulterated products in the marketed samples of turmeric [167]. For turmeric oils or oleoresins from rhizomes of $C$. curcuma adulterated with leaf oils, GS-MS or NMR techniques will be helpful. Because essential oils from leaves or flowers of C. longa are usually dominated by monoterpenes while those from roots and rhizomes mainly contain sesquiterpenes, this chemical feature and color difference could be used to distinguish the leaf or flower oils from turmeric oils derived from rhizome or root of C. longa.

However, the molecular methods as tools for authentication of species/variety have limitations. There are significant variations in compositions of both curcuminoids and essential oils of $C$. longa with genotypes, environments, 
harvest methods and season, dry process, and storage conditions. As a result, chemical analysis may not provide reliable authentication in some cases, particularly when involving multiple species or hybrids. Genetic methods directly detect genotypes of Curcuma, however, it may be difficult to isolate or amplify DNA and develop DNA fingerprints and the replication could be problematic under certain circumtances. Like morphological and anatomic methods, molecular methods may be more useful in identification of $C$. longa than characterization of other species in the adulterated samples. Therefore, it would be better to apply chromatographic and NMR techniques as well as DNA markers of the questionable samples with morphological and anatomic data as well as GAP (good agricultural practices) and other information provided by the farmers and manufacturers.

\section{Microbial, Heavy Metal, and Pesticide Analyses}

The microbial, heavy metal, and pesticide contents in all turmeric products (including plant matters, extracts, and isolates) should be investigated by authentic methods (e.g., USP $<61>,<231>$, and $<561>$ methods). For example, authors recently tested ground turmeric and ethanol extracts by using EPA (Environmental Protection Agency, USA) Method 200.2 (Table 5). Levels of $\mathrm{Ag}, \mathrm{Cd}, \mathrm{Se}$, and $\mathrm{Cr}$ were below the detection limit (ppm) by ThermoFisher XSP Intrepid Radial Dedicated Inductively Coupled Plasma and levels of As and $\mathrm{Hg}$ were below the detection limit by Atomic $\mathrm{Ab}$ sorption (ppb) by PerkinElmer AA700 Analyst Atomic Absorption with a Graphite Furnace and Mercury Hydride System. $\mathrm{Ba}$ and $\mathrm{Ni}$ were detectable in all three plant samples but both were at below detectable levels in the ethanolic extract of turmeric. Lead levels in both ground turmeric and ethanol extract were between 104.6 to $328.4 \mathrm{ppb}$, much lower than the minimum levels of $10 \mathrm{mg} / \mathrm{kg}(10,000 \mathrm{ppb})$ for turmeric recommended by WHO (WHO 1999).

For turmeric oleoresins and curcumin (1) (curcuminoids), residual solvents could be a problem. The residual solvent and heavy metal contents are limited to $25 \mathrm{mg} / \mathrm{kg}$ for hexane, $30 \mathrm{mg} / \mathrm{kg}$ for actone, dichloromethane, and 1,2dichloroethane, $50 \mathrm{mg} / \mathrm{kg}$ for ethanol, methanol, and isopropanol, $3 \mathrm{mg} / \mathrm{kg}$ for As and $2 \mathrm{mg} / \mathrm{kg}$ for $\mathrm{Pb}$, according to JECFA specifications (FNP 52 add. 11, 2003) [168].

\section{CONCLUSIONS}

Turmeric (Curcuma longa L.) is one of the most extensively phytochemically investigated plant species. At least 235 compounds have been isolated or detected from leaves, flowers, roots, and rhizomes of C. longa, including 22 diarylheptanoids and diarylpentanoids, eight phenylpropene and other phenolic compounds, 68 monoterpenes, 109 sesquiterpenes, five diterpenes, three triterpenoids, four sterols, two alkaloids, and 14 other compounds. Curcuminoids and essential oils have shown various bioactivities in in vitro and in vivo bioassays. Curcumin is one of the most studied chemopreventive agents and showed promising results in cell culture, animal research, and clinical trials. Curcuminoids in turmeric are primarily accumulated in rhizomes. The essential oils from leaves and flowers are usually dominated by monoterpenes while the major part of the oil from roots and rhizomes contain sesquiterpenes. The contents of curcuminoids in turmeric rhizomes vary often with varieties, locations, sources, and cultivation conditions, while significant variations were observed in composition of essential oils of turmeric rhizomes with varieties and geographical locations. Furthermore, both curcuminoids and essential oils vary in contents with different extraction methods and are unstable with extraction and storage processes. As a result, commercial turmeric products (whole rhizomes, ground turmeric, turmeric oils, turmeric oleoresin, and "curcumin") have significant variations in composition of bioactive compounds. Ethanol extraction showed advantages in both effective extraction and stability of active curcuminoids. Curcumin (1), demethoxycurcumin (2), and bisdemethoxycurcumin (5) can be used as marker compounds for the quality control of rhizomes, powders, and extract ("curcumin") products with minimum limit of the contents. The major ketonic sesquiterpenes (Ar-turmerone (99), $\alpha$-turmerone (100), and $\beta$ turmerone (101)) can be used to control the product quality of turmeric oil and oleoresin products. Authentication of turmeric products can be achieved by using chromatographic and NMR techniques and DNA markers of the questionable samples with morphological and anatomic data as well as GAP and other information provided by the farmers and manufacturers. Other quality aspects such as the microbial, heavy metal, and pesticide contents in all turmeric products (including plant matters, extracts, and isolates) should be investigated by authentic methods as well.

Table 5. Heavy metal analysis of the plant samples (N.D.: Not Detected)

\begin{tabular}{|c|c|c|c|c|c|c|c|c|c|}
\hline & \multicolumn{6}{|c|}{$\begin{array}{c}\text { ThermoFisher XSP Intrepid Radial Dedicated } \\
\text { Inductively Coupled Plasma } \\
\text { (ppm) }\end{array}$} & \multicolumn{3}{|c|}{$\begin{array}{c}\text { AA700 Analyst Atomic Absorp- } \\
\text { tion } \\
(\mathrm{ppb})\end{array}$} \\
\hline & $\mathrm{Ag}$ & $\mathrm{Ba}$ & $\mathrm{Cd}$ & $\mathrm{Cr}$ & $\mathrm{Se}$ & $\mathrm{Ni}$ & As & $\mathrm{Hg}$ & $\mathrm{Pb}$ \\
\hline Wavelength $(\mathrm{nm})$ & 328.068 & 230.424 & 228.802 & 284.325 & 196.090 & 231.604 & 193.7 & 253.7 & 283.3 \\
\hline Ground Turmeric & N.D. & 13.86 & N.D. & N.D. & N.D. & 1.382 & N.D. & N.D. & 222.4 \\
\hline Ethanol Extract & N.D. & N.D. & N.D. & N.D. & N.D. & N.D. & N.D. & N.D. & 118.4 \\
\hline
\end{tabular}

Note: authors' unpublished data. 


\section{ABBREVIATIONS}

\begin{tabular}{|c|c|c|}
\hline AP-1 & $=$ & Activator protein 1 \\
\hline BCL2 & $=$ & B-cell lymphoma 2 \\
\hline BCL2L1 & $=$ & BCL2-like 1 \\
\hline $\mathrm{CE}$ & $=$ & Capillary electrophoresis \\
\hline $\mathrm{COX}-1$ & $=$ & Cyclooxigenase-1 \\
\hline $\mathrm{COX}-2$ & $=$ & Cyclooxigenase-2, \\
\hline EPA & $=$ & Environmental Protection Agency, USA \\
\hline GC-MS & $=$ & Gas chromatography-mass spectrometry \\
\hline GAP & $=$ & Good agricultural practices \\
\hline HPLC & $=$ & High performance liquid chromatography \\
\hline $\begin{array}{l}\text { HPLC- } \\
\text { ESI-MS }\end{array}$ & $=$ & $\begin{array}{l}\text { high-performance liquid chromatography- } \\
\text { electrospray ionization tandem-mass } \\
\text { spectrometry }\end{array}$ \\
\hline ISSR & $=$ & Inter simple sequence repeats \\
\hline IL-1 & $=$ & Interleukin-1 \\
\hline IL-6 & $=$ & Interleukin-6 \\
\hline JECFA & $=$ & $\begin{array}{l}\text { Joint FAO/WHO Expert Committee on } \\
\text { Food Additives }\end{array}$ \\
\hline LAMP & $=$ & Loop-mediated isothermal amplification) \\
\hline LC-MS & $=$ & Liquid chromatography-mass spectrometry \\
\hline LOX & $=$ & Lipoxygenase \\
\hline $\mathrm{NF}-\kappa \mathrm{B}$ & $=$ & $\begin{array}{l}\text { Tumor necrosis factor (TNF)-induced nu- } \\
\text { clear factor-кB }\end{array}$ \\
\hline NMR & $=$ & Nuclear magnetic resonance \\
\hline RAPD & $=$ & Random amplified polymorphic DNA \\
\hline SFE & $=$ & Supercritical fluid extraction \\
\hline STEs & $=$ & Standardized therapeutic extracts \\
\hline STMs & $=$ & Small therapeutic molecules \\
\hline TNF & $=$ & Tumor necrosis factor \\
\hline $\operatorname{trnS}-\operatorname{trnfM}$ & $=$ & Intergenic spacer between trnS and trnfM \\
\hline USP & $=$ & The United States Pharmacopeia \\
\hline $\mathrm{HO}$ & $=$ & World Health Organization \\
\hline
\end{tabular}

\section{REFERENCES}

[1] Remadevi, R.; Surendran, E.; Kimura, T. Turmeric in Traditional medicine. In Turmeric: the genus Curcuma, Ravindran, P. N.; Nirmal Babu, K.; Sivaraman, K., Eds. CRC Press: Boca Raton, London, New York, 2007, pp. 409-436.

[2] Sasikumar, B. Genetic resources of Curcuma: diversity, characterization and utilization. Plant Gen. Resour., 2005, 3, 230-251.

[3] Jurenka, S. Anti-inflammatory properties of curcumin, a major constituent of Curcuma longa: a review of preclinical and clinical research. Altern. Med. Rev., 2009, 14, 141-153.

[4] Behura, S.; Sahoo, S.; Srivastava, V. K. Major constituents in leaf essential oils of Curcuma longa L. and Curcuma aromatica Salisb . . Curr. Sci., 2002, 83, 1312-1313.

[5] China, E. C. O. T. P. O. P. S. R. O. The Pharmacopoeia of People's Republic of China. Chemical Industry Press: Beijing, 2005.

[6] Chavalittumrong, P.; Dechatiwongse, T. Quality evaluation of turmeric. Thai. J. Pharm. Sci. , 1988, 13, 317-327.
[7] Chavalittumrong, P.; Jirawattanapong, W. Variation of active constituents of Curcuma domestica rhizomes at different ages. Thai. J. Pharm. Sci., 1992, 16, 165-174.

[8] Taylor, S. J.; McDowell, I. J. Determination of the curcuminoid pigments in turmeric (Curcuma domestica Val) by reverse-phase high-performance liquid chromatography. Chromatographia, 1992, 34, 73-77.

[9] WHO. WHO monographs on selected medicinal plants. World Health Organization: Geneva, 1999.

[10] Funk, J. L.; Oyarzo, J. N.; Frye, J. B.; Chen, G.; Lantz, R. C.; Jolad, S. D.; Sólyom, A. M.; Timmermann, B. N. Turmeric extracts containing curcuminoids prevent experimental rheumatoid arthritis. J. Nat. Prod., 2006, 69, 351-355.

[11] Deshpande, S. S.; Ingle, A., D.; Maru, G. B. Inhibitory effects of curcumin-free aqueous turmeric extract on benzo[a]pyrene-induced forestomach papillomas in mice. Cancer Lett., 1997, 118, 79-85.

[12] Bengmark, S.; Mesa, M. D.; Gil, A. Plant-derived health: the effects of turmeric and curcuminoids. Nutr. Hosp., 2009, 24, 273281.

[13] Azuine, M. A.; Bhide, S. V. Adjuvant chemoprevention of experimental cancer: catechin and dietary turmeric in forestomach and oral cancer models. J. Ethnopharmacol., 1994, 44, 211-217.

[14] Aggarwal, B. B.; Kunnumakkara, A. B.; Harikumar, K. B.; Tharakan, S. T.; Sung, B.; Anand, P. Potential of spice-derived phytochemicals for cancer prevention. Planta Med., 2008, 74, 15601569 .

[15] Funk, J. L.; Frye, J. B.; Oyarzo, J. N.; Kuscuoglu, N.; Wilson, J.; McCaffrey, G.; Stafford, G.; Chen, G.; Lantz, R. C.; Jolad, S. D.; Sólyom, A. M.; Kiela, P. R.; Timmermann, B. N. Efficacy and mecganism of action of turmeric supllements in the treatment of experimental arthritis. Arthritis Rheum., 2006, 54, 3452-3464.

[16] Bar-Sela, G.; Epelbaum, R.; Schaffer, M. Curcumin as an anticancer agent: review of the gap between basic and clinical applications. Curr. Med. Chem., 2010, 17, 190-197.

[17] Kuttan, R.; Bhanumathy, P.; Nirmala, K.; George, M. C. Potential anticancer activity of turmeric (Curcuma longa). Cancer Lett., 1985, 29, 197-202.

[18] Aggarwal, B. B.; Bhatt, I. D.; Ichikawa, H.; Ahn, K. S.; Sethi, G.; Sandur, S. K.; Sundaram, C.; Seeram, N.; Shishodia, S. Curcumin Biological and medicinal properties. In Turmeric: The genus Curcuma, Ravindran, P. N.; Nirmal Babu, K.; Sivaraman, K., Eds. CRC Press: Boca Raton, London, New York, 2007, pp. 297-368.

[19] Duvoix, A.; Blasius, R.; Delhalle, S.; Schnekenburger, M.; Morceau, F.; Henry, E.; Dicato, M.; Diederich, M. Chemopreventive and therapeutic effects of curcumin. Cancer Lett., 2005, 223, 181-190.

[20] Funk, J. L.; Oyarzo, J. N.; Frye, J. B.; Chen, G.; Lantz, R. C.; Jolad, S. D.; Sólyom, A. M.; Kiela, P. R.; Timmermann, B. N. Turmeric extracts containing curcuminoids prevent experimental rheumatoid arthritis. J. Nat. Prod., 2006, 69, 351-355.

[21] Sandur, S. K.; Pandey, M. K.; Sung, B.; Ahn, K. S.; Murakami, A.; Sethi, G.; Limtrakul, P.; Badmaev, V.; Aggarwal, B. B. Curcumin, demethoxycurcumin, bisdemethoxycurcumin, tetrahydrocurcumin and turmerones differentially regulate anti-inflammatory and antiproliferative responses through a ROS-independent mechanism. Carcinogenesis, 2007, 28, 1765-1773.

[22] Potterat, O.; Hamburger, M. Drug discovery and development with plant-derived compounds. In Progress in Drug Research: Natural Compounds as Drugs, Petersen, F.; Amstutz, R., Eds. Birkhäuser Verlag AG: Birkhäuser, Basel, Boston, Berlin, 2008, Vol. 1, pp. 45-118.

[23] Shehzad, A.; Lee, Y. S. Curcumin: Multiple molecular targets mediate multiple pharmacological actions: A review. Drugs Fut., 2010, 35, 113-120.

[24] Bengmark, S.; Mesa, M. D.; Gil, A. Plant-derived health - the effects of turmeric and curcuminoids. Nutr. Hosp., 2009, 24, 273 281.

[25] Singh, S.; Khar, A. Biological effect of curcumin and its role in cancer chemoprevention and therapy. Anti-Cancer Agents Med. Chem., 2006, 6, 259-270.

[26] Maheshwari, R. K.; Singh, A. K.; Gaddipati, J.; Srimal, R. C. Multiple biological activities of curcumin: A short review. Life Sci. 2006, 78, 2081-2087.

[27] Rivera-Espinoza, Y.; Muriel, P. Pharmacological actions of curcumin in liver diseases or damage. Liver Int., 2009, 29, 1457-1466. 
[28] Mohanty, I.; Singh Arya, D.; Dinda, A.; Joshi, S.; Talwar, K. K.; Gupta, S. K. Protective effects of Curcuma longa on ischemiareperfusion induced myocardial injuries and their mechanisms. Life Sci., 2004, 75, 1701-1711.

[29] Honda, S.; Aoki, F.; Tanaka, H.; Kishida, H.; Nishiyama, T.; Okada, S.; Matsumoto, C.; Abe, K.; Mae, T. Effects of ingested turmeric oleoresin on glucose and lipid metabolisms in obese diabetic mice: a DNA microarray study. J. Agric. Food Chem., 2006, 54, 9055-9062.

[30] Kuroda, M.; Mimaki, Y.; Nishiyama, T. Hypoglycemic effects of turmeric (Curcuma longa L. rhizomes) on genetically diabetic KKAy mice. Bio. Pharm. Bull., 2005, 28, 937-939.

[31] Shytle, R. D.; Bickford, P. C.; Rezai-zadeh, K.; Hou, L.; Zeng, J.; Tan, J.; Sanberg, P. R.; Sanberg, C. D.; Roschek Jr., B.; Fink, R. C.; Alberte, R. S. Optimized turmeric extracts have potent antiamyloidogenic effects. Cur. Alzheimer Res., 2009, 6, 564-571.

[32] Cho, J. Y.; Choi, G. J.; Lee, S. W.; Lim, H. K.; Jang, K. S.; Lim, C. H.; Cho, K. Y.; Kim, J. C. In vivo antifungal activity against various plant pathogenic fungi of curcuminoids isolated from the rhizomes of Curcuma longa. Plant Path. J., 2006, 22, 94-96.

[33] Haddad, M.; Sauvain, M.; Deharo, E. Curcuma as a parasiticidal agent: a review. Planta Med., 2010, 77(6), 672-678.

[34] Abbas, R. Z.; Iqbal, Z.; Khan, M. N.; Zafar, M. A.; Zia, M. A. Anticoccidial activity of Curcuma longa L. in broilers. Brazilian Arch. Biol. Technol., 2010, 53, 63-67.

[35] Cousins, M.; Adelberg, J.; Chen, F.; Rieck, J. Antioxidant capacity of fresh and dried rhizomes from four clones of turmeric (Curcuma longa L.) grown in vitro. Ind. Crop. Prod., 2007, 25, 129-135.

[36] Jayaprakasha, G. K.; Rao, L. J. M.; Sakariah, K. K. Antioxidant activities of curcumin, demethoxycurcumin and bisdemethoxycurcumin. Food Chem., 2006, 98, 720-724.

[37] Hamaguchi, T.; Ono, K.; Yamada, M. Review: curcumin and Alzheimer's disease. CNS Neurosci. Therapeut., 2010, 16, 285-297.

[38] Alappat, L.; Awad, A. B. Curcumin and obesity: evidence and mechanisms. Nutr. Rev., 2010, 68, 729-738.

[39] Dairam, A.; Limson, J. L.; Walkins, G. M.; Antunes, E.; Daya, S. curcuminoids, curcumin, and demethoxycurcumin reduce leadinduced memory deficits in male wistar rats. J. Agric. Food Chem., 1007, 55, 1039-1044.

[40] Singh, G.; Singh, O. P.; Maurya, S. Chemical and biocidal investigations on essential oils of some Indian Curcuma species. Prog. Cryst. Grow. Character. Mater., 2002, 45, 75-81.

[41] Apisariyakui, A.; Vanittanakom, N.; Buddhasukh, D. Antifungal activity of turmeric oil extracted from Curcuma longa (Zingiberaceae) J. Ethnopharmacol., 1995, 49, 163-169.

[42] Negi, P. S.; Jayaprakasha, G. K.; Rao, L. J. M.; Sakariah, K. K. Antibacterial activity of turmeric oil: a byproduct from curcumin manufacture. J. Agric. Food Chem., 1999, 47, 4297-4300.

[43] Lee, H. S.; Choi, K. J.; Cho, K. Y.; Ahn, Y. J. Fungicidal activity of ar-turmerone identified in Curcuma longa rhizome against six phytopathogenic fungi. Agric. Chem. Biotechnol., 2003, 46, 25-28.

[44] Ajaiyeoba, E. O.; Sama, W.; Essien, E. E.; Olayemi, J. O.; Ekundayo, O.; Walker, T. M.; Setzer, W. N. Larvicidal Activity of Turmerone-Rich Essential Oils of Curcuma longa. Leaf and Rhizome from Nigeria on Anopheles gambiae. Pharm. Biol., 2008, 46, 279-282.

[45] Mau, J.; Laib, E.; Wang, N.; Chen, C.; Chang, C.; Chyau, C. Composition and antioxidant activity of the essential oil from Curcuma zedoaria. Food Chem., 2003, 82, 583-591.

[46] Yasni, S.; Imaizumi, K.; Sin, K.; Sugano, M.; Nonaka, G. Identification of an active principle in essential oils and hexane-soluble fractions of Curcuma xanthorrhiza Roxb. showing triglyceridelowering action in rats. Food Chem. Toxicol., 1994, 32, 273-278.

[47] Li, S. Y.; Yuan, W.; Yang, P. Y.; Antoun, M. D.; Balick, M. J.; Cragg, G. M. Pharmaceutical crops: An overview. Pharm. Crops, 2010, 1, 1-17.

[48] Olojede, A. O.; Nwokocha, C. C.; Akinpelu, A. O.; Dalyop, T. Effect of variety, rhizome and seed bed types on yield of turmeric (Curcuma longa L) under a humid tropical agro-ecology. Adv. Bio. Res., 2009, 3, 40-42.

[49] Chempakam, B.; Parthasarathy, V. A. Turmeric. In Chemistry of Spice, Parthasarathy, V. A.; Chempakam, B.; Zachariah, T. J., Eds. CABI: Cambridge, 2008; pp 97-123.

[50] Ratnambal, M. J. Evaluation of turmeric accession for quality. Qual. Plantarum, 1986, 36, 243-252.
[51] Ravindran, P. N.; Nirmal Babu, K.; Shiva, K. N. Botany and crop improvement of turmeric. In Turmeric: the Genus Curcuma, Ravindran, P. N.; Nirmal Babu, K.; Sivaraman, K., Eds. CRC Press: Boca Raton, London, New York, 2007; pp 15-70.

[52] Cintra, M. M. D. F.; Pinheiro, J. B.; Sibov, S. T. Genetic divergence among Curcuma longa L. accessions. Crop Breed. Appl. Biotechnol., 2005, 5, 410-417.

[53] Nahar, L.; Sarker, S. D. Phytochemistry of the genus Curcuma. In Turmeric: the genus Curcuma, Ravindran, P. N.; Nirmal Babu, K.; Sivaraman, K., Eds. CRC Press: Boca Raton, 2007; pp 71-106.

[54] Lv, H.; She, G. Naturally occurring diarylheptanoids. Pharm Crops, 2010, 5, 1687-1708.

[55] Milobedzka, J.; Kostanecki, S. V.; Lampe, V. Curcumin. Chem. Ber., 1910, 43, 2163-2170.

[56] Pfeiffer, E.; Hhle, S.; Solyom, A. S.; Metzler, M. Studies on the stability of turmeric constituents. J. Food Engineer., 2003, 56, 257 259.

[57] Gupta, A. P.; Gupta, M. M.; Kumar, S. Simultaneous determination of curcuminoids in Curcuma samples using high performance thin layer chromatography. J. Liq. Chromatog. Related Technol., 1999, 22, 1561-1569.

[58] Jitoe, A.; Masuda, T.; Tengah, I. G. P.; Suprapta, D. N.; Gara, I. W.; Nakatani, N. Antioxidant activity of tropical ginger extracts and analysis of the contained curcuminoids. J. Agric. Food Chem., 1992, 40, 1337-1340.

[59] Bos, R.; Windono, T.; Woerdenbag, H. J.; Boersma, Y. L.; Koulman, A.; Kayser, O. HPLC-photodiode array detection analysis of curcuminoids in Curcuma species indigenous to Indonesia. Phytochem. Anal., 2007, 18, 118-122.

[60] Huang, J.; Ogihara, Y.; Gonda, R.; Takeda, T. Novel biphenyl ether lignans from the rhizomes of Curcuma chuanyujin. Chem. Pharm. Bull., 2000, 48, 1228-1229.

[61] Uehara, S.; Yasuda, I.; Takeya, K.; Itokawa, H. Terpenoids and curcuminoids of the rhizoma of Curcuma xanthorrhiza Roxb. J. Pharm. Soc. Jap., 1992, 112, 817-823.

[62] Syu, W. J.; Shen, C. C.; Don, M. J.; Ou, J. C.; Lee, G. H.; Sun, C. M. Cytotoxicity of Curcuminoids and Some Novel Compounds from Curcuma zedoaria. J. Nat. Prod., 1998, 61, 1531-1534.

[63] Kiuchi, F.; Goto, Y.; Sugimoto, N.; Akao, N.; Kondo, K.; Tsuda, Y. Nematocidal activity of turmeric: synergistic action of curcuminoids. Chem. Pharm. Bull., 1993, 41, 1640-1643.

[64] Yamada, K.; Subeki; Nabeta, K.; Yamasaki, M.; Katakura, K.; Matsuura, H. Isolation of Antibabesial Compounds from Brucea javanica, Curcuma xanthorrhiza, and Excoecaria cochinchinensis. Biosci. Biotechnol. Biochem., 2009, 73, 776-780.

[65] Park, B. S.; Kim, G. J.; Kim, M. R.; Lee, S. E.; Takeoka, G. R.; Oh, K. B.; Kim, J. H. Curcuma longa L. constituents inhibit sortase A and Staphylococcus aureus cell adhesion to fibronectin. J. Agric. Food Chem., 2005, 53, 9005-9009.

[66] Roth, G. N.; Chandra, A.; Nair, N. G. Novel bioactivities of Curcuma longa constituents. J. Nat. Prod., 1998, 61, 542-545.

[67] Li, W.; Wang, S. S.; Feng, J. T.; Xiao, Y. S.; Xue, X. Y.; Zhang, H.; Wang, Y. Q.; Liang, X. M. Structure elucidation and NMR assignments for curcuminoids from the rhizomes of Curcuma longa. Magn. Reson. Chem., 2009, 47, 902-908.

[68] Kita, T.; Imai, S.; Sawada, H.; Seto, H. Isolation of dihydrocurcuminoids from cell clumps and their distribution in various parts of turmeric (Curcuma longa). Biosci. Biotechnol. Biochem., 2009, 73, 1113-1117.

[69] Park, S. Y.; Kim, D. S. L. H. Discovery of natural products from Curcuma longa that protect cells from Beta-Amyloid insult: a drug discovery effort against Alzheimer's disease. J. Nat. Prod., 2002, $65,1227-1231$.

[70] Kiuchi, F.; Goto, Y.; Sugimoto, N.; Akao, N.; Kondo, K.; Tsuda, Y. Nematocidal activity of turmeric: synergistic action of curcuminoids. Chem Pharm Bull (Tokyo), 1993, 41, 1640-1643.

[71] Wang, L. Y.; Zhang, M.; Zhang, C. F.; Wang, Z. T. Diaryl derivatives from the root tuber of Curcuma longa. Biochem. System. Ecol., 2008, 36, 476-480.

[72] Chen, J. J.; Tsai, C. S.; Hwang, T. L.; Shieh, P. C.; Chen, J. F.; Sung, P. J. Sesquiterpenes from the rhizome of Curcuma longa with inhibitory activity on superoxide generation and elastase release by neutrophils. Food Chem., 2010, 119, 974-980.

[73] Zeng, Y. C.; Qiu, F.; Takahashi, K.; Liang, J. M.; Qu, G. X.; Yao, $\mathrm{X}$. S. New sesquiterpenes and calebin derivatives from Curcuma longa. Chem. Pharm. Bull., 2007, 55, 940-943. 
[74] Oguntimein, B. O.; Weyerstahl, P.; Marshall, H. Essential oil of Curcuma longa L. leaves. Flav. Frag. J., 1990, 5, 89-90.

[75] Leela, N. K.; Tava, A.; Shafi, P. M.; John, S. P.; Chempakam, B. Chemical composition of essential oils of turmeric (Curcuma longa L.). Acta Pharm., 2002, 52, 137-141.

[76] Chowdhury, J. U.; Nandi, N. C.; Bhuiyan, M. N. I.; Mobarok, M. H. Essential oil constituents of the rhizomes of two types of Curcuma longa of Bangladesh. Bangladesh J. Sci. Ind. Res., 2008, 43, 259-266.

[77] Gopalan, B.; Goto, M.; Kodama, A.; Hirose, T. Supercritical carbon dioxide extraction of turmeric (Curcuma longa). J. Agric. Food Chem., 2000, 48, 2189-2192.

[78] Usman, L. A.; Hamid, A. A.; George, O. C.; Ameen, O. M.; Muhammad, N. O.; Zubair, M. F.; A., L. Chemical composition of rhizome essential oil of Curcuma longa L. growing in North Central Nigeria. World J. Chem., 2009, 4, 178-181.

[79] Ma, X.; Gang, D. R. Metabolic profiling of turmeric (Curcuma longa L.) plants derived from in vitro micropropagation and conventional greenhouse cultivation. J. Agric. Food. Chem., 2006, 54, 9573-9583.

[80] Zeng, Y. C.; Liang, J. M.; Qu, G. X.; Qiu, F. Chemical constituents of Curcuma longa I: bisabolane sesquiterpenes. Acta Pharm. Sin., 2007, 17, 738-741.

[81] Chassagnez-Me'ndez, A. L.; Machado, N. T.; Araujo, M. E.; Maia, J. G.; Meireles, M. A. A. Supercritical $\mathrm{CO}_{2}$ extraction of curcumins and essential oil from the rhizomes of turmeric (Curcuma longa L.). Ind. Eng. Chem. Res., 2000, 39, 4729-4733.

[82] Li, W.; Feng, J. T.; Xiao, Y. S.; Wang, Y. Q.; Xue, X. Y.; Liang, $\mathrm{X}$. M. Three novel terpenoids from the rhizomes of Curcuma longa. J. Asian Nat. Prod. Res., 2009, 11, 569-575.

[83] Golding, B. T.; Pombo, E.; Christopher, J. S. Turmerones: isolation from turmeric and their structure determination. J. Chem. Soc. Chem. Commun., 1982, 6, 363-364.

[84] Cooray, N. F.; Jansz, E. R.; Ranatunga, J.; Wimalasena, S. Effect of maturity on some chemical constituents of tumeric (Curcuma longa L.). J. Natn. Sci. Coun. Sri Lanka, 1988, 16, 39-51.

[85] Nigam, M. C.; Ahmed, A. Curcuma longa: terpenoid composition of its essential oil. Indian Perfumer., 1991, 3, 201-205.

[86] Sharma, R. K.; Misra, B. P.; Sarma, T. C.; Bordoloi, A. K.; Pathak, M. G.; Leclercq, P. A. Essential oils of Curcuma longa L. from Bhutan. J. Essent. Oil Res., 1997, 9, 589-592.

[87] Imai, S.; Morikiyo, M.; Furihata, K.; Hayakawa, Y.; Seto, H. Turmeronol A and turmeronol B, new inhibitors of soybean lipoxygenase. Agri. Biol. Chem., 1990, 54, 2367-2371.

[88] Manzan, A. C. C. M.; Toniolo, F. S.; Bredow, E.; Povh, N. P. Extraction of Essential Oil and Pigments from Curcuma longa [L.] by Steam Distillation and Extraction with Volatile Solvents. J. Agric. Food Chem., 2003, 51, 6802-6807.

[89] Nishiyama, T.; Mae, T.; Kishida, H.; Tsukagawa, M.; Mimaki, Y.; Kuroda, M.; Sashida, Y.; Takahashi, K.; Kawada, T.; Nakagawa, K.; Kitahara, M. Curcuminoids and sesquiterpenoids in turmeric (Curcuma longa L.) suppress an increase in blood glucose level in type 2 diabetic KK-Ay mice. J. Agric. Food Chem., 2005, 53, 959963.

[90] Ohshiro, M.; Kuroyanagi, M.; Ueno, A. Structures of sesquiterpenes from Curcuma longa. Phytochemistry, 1990, 29, 2201-2205.

[91] Wang, L. Y.; Zhang, M.; Zhang, C. F.; Wang, Z. T. Alkaloid and sesquiterpenes from the root tuber of Curcuma longa. Acta Pharm. Sin., 2008, 43, 724-727.

[92] Braga, M. E. M.; Leal, P. F.; Carvalho, J. E.; Meireles, M. A. A. Comparison of yield, composition, and antioxidant activity of turmeric (Curcuma longa L.) extracts obtained using various techniques. J. Agric. Food Chem., 2003, 51, 6604-6611.

[93] Awasthi, P. K.; Dixit, S. C. Chemical composition of Curcuma Longa leaves and rhizome oil from the plains of Northern India. Pharmacognosy, 2009, 1, 312-316.

[94] Liu, C.; Sun, B.; Huang, J.; Gao, H.; Wen, S.; Wu, L. A novel sesquiterpene from Curcuma longa. Asian J. Trad. Med., 2007, 2, 82-84.

[95] Mohamed, S. M.; El-Gengaihi, S. E.; Motawe, H. M. Terpenoid from Curcuma longa. Egypt. J. Pharm. Sci., 2003, 43, 139-151.

[96] Wu, Z. H.; Huang, S. W.; Liu, C. Y.; Sun, B. H.; Huang, J. S.; Wu, L. J. A novel compound from Curcuma longa. Asian J. Trad. Med., 2008, 3, 199-202.

[97] Kobayashi, T.; Miyazaki, A.; Matsuzawa, A.; Kuroki, Y.; Shimamura, T.; Yoshida, T.; Yamamoto, Y. Change in curcumin content of rhizome in turmeric and yellow zedoary. Nippon Sakumotsu Gakkai Kiji, 2010, 79 (1), 10-15.

[98] Rakhunde, S. D.; Munjal, S. V.; Patil, S. R. Curcumin and essential oil contents of some commonly grown turmeric (Curcuma longa L.) cultivars in Maharashtra. J. Food Sci. Technol., 1998, 35, 352354.

[99] Jayaprakasha, G. K.; Rao, L. J. M.; Sakariah, K. K. Improved HPLC method for determination of curcumin, demethoxycurcumin, and bisdemethoxycurcumin. J. Agric. Food Chem., 2002, 50, 36683672 .

[100] Tanaka, K.; Kuba, Y.; Sasaki, T.; Hiwatashi, F.; Komatsu, K. Quantitation of curcuminoids in Curcuma rhizome by near-infared spectroscopic analysis. J. Agric. Food Chem., 2008, 56, 8787-8792.

[101] Garg, S. N.; Bansal, R. P.; Gupta, M. M.; Kumar, S. Variation in the rhizome essential oil and curcumin contents and oil quality in the land races tumeric Curcuma longa of North Indian plains. Flav. Frag. J., 1999, 14, 315-318.

[102] Tayyem, R. F.; Heath, D. D.; Al-Delaimy, W. K.; Rock, C. L. Curcumin content of turmeric and curray powders. Nutrition Cancer, 2006, 55, 126-131.

[103] Thaikert, R.; Paisooksantivatana, Y. Variation of total curcuminoids content, antioxidant activity and generic diversity in turmeric (Curcuma longa L.) collections. Kasetsart J., 2009, 43, 507-518.

[104] Sasikumar, B.; Ravindran, P. N.; Johnson, K. G. Breeding ginger and turmeric. Indian Cocoa, Arecanut Sp. J., 1994, 18, 10-12.

[105] TØnnesen, H. H.; Karlsen, J.; Adhikary, S. R.; Pandey, R. Variation of total curcuminoids content, antioxidant activity and generic diversity in turmeric (Curcuma longa L.) collections. Kasetsart J., 1989, 43, 507-518.

[106] Chi, H.; Kim, H. Curcumin content of cultivated turmeric in Korea Saengyak Hakhoechi, 1983, 14 (2), 67-9.

[107] Pothitirat, W.; Gritsanapan, W. Variability of curcuminoids: antioxidantive components in ethanolic turmeric extract determined by UV and HPLC methods. Acta Hort. (ISHS), 2008, 786, 175-184.

[108] Hossain, A. H.; Ishimine, Y. Growth, yield and quality of turmeric (Curcuma longa L.) cultivated on dark-red soil, gray, and red soil in Okinawa, Japan. Plant Prod Sci., 2005, 8, 482-486.

[109] Karthikeyan, P. K.; Ravichandran, M.; Imas, P.; Assaraf, M. The effect of potassium on the yield and quality of turmeric (Curcuma longa). . E-ifc, no. 21, September 2009.

[110] Suresh, D.; Manjunatha, H.; Srinivasan, K. Effect of heat processing of spices on the concentrations of their bioactive principles: Turmeric (Curcuma longa), red pepper (Capsicum annuum) and black pepper (Piper nigrum). J. Food Comp. Anal., 2007, 20, 346351.

[111] Bambirra, M. L. A.; Hunqueira, R. G.; Glória, M. B. A. Influence of post harvest processing conditions on yield and quality of ground tumeric (Curcuma longa L.). Brazilian Arch. Biol. Technol., 2002, 45, 423-429.

[112] Satheesan, K. V.; Ramadasan, A. Effect of growth retardant CCC on growth and productivity of turmeric under monoculture and in association with coconut. J. Plantation Crops, 1988, 16, 140-143.

[113] Dixit, D.; Srivastava, N. K.; Sharma, S. Effect of Fe ${ }^{-}$deficiency on growth, physiology, yield and enzymatic activity in selected genotypes of turmeric (Curcuma longa L.). J. Plant Biol., 1999, 26 237-241.

[114] Dixit, D.; Srivastava, N. K.; Kumar, R.; Sharma, S. Cultivar variation in yield, metabolite translocation and partitioning of ${ }^{14} \mathrm{CO}_{2}$ assimilated photosynthate into essential oil and curcumin of turmeric (Curcuma longa L.) J. Plant Biol., 2002, 29, 65-70.

[115] Dixit, D.; Srivastava, N. K. Partitioning of 14C-photosynthate of leaves in roots, rhizome, and in essential oil and curcumin in turmeric (Curcuma longa L.). Photosynthetica, 2002, 38, 275-280.

[116] Dixit, D.; Srivastava, N. K.; Kumar, R. Intraspecific variation in yield capacity of turmeric, Curcuma longa with respect to metabolic translocation and partitioning of ${ }^{14} \mathrm{CO}_{2}$ photoassimilate into essential oil and curcumin J. Med. Arom. Plant Sci., 2001, 22-23, 269-274

[117] Mehta, K. G.; Raghava Rao, D. V.; Patel, S. H. Relative curcumin content during varu=ious growth stages in the leaves and rhizomes of three cultivars of Curcuma longa and C. amada. In Proceedings of National Seminar on Ginger and Turmeric, Nair, M. K.; Premkumar, T.; Ravindran, P. N.; Sarma, Y. R., Eds. Central Plantation Crops Research Institute: Kasaragod, 1980; pp 76-78.

[118] Paramasivam, M.; Aktaroi, M. W.; Poi, R.; Banerjee, H.; Bandyopadhyay, A. Occurrence of curcuminoids in Curcuma longa : A 
quality standardization by HPTLC. J. Bangladesh Pharm. Soc., 2008, 3, 55-58.

[119] Qu, Y.; Xu, F. M.; Nakamura, S.; Matsuda, H.; Pongpiriyadacha, Y.; Wu, L. J.; Yoshikawa, M. Sesquiterpenes from Curcuma comosa. J. Nat. Med., 2009, 63, 102-104.

[120] Sukari, M. A.; Tang, S. W.; Saad, S. M.; Rashid, N. Y.; Rahmani, M.; Lajis, N. H.; Taufiq-Yap, Y. H. Bioactive Sesquiterpenes from Curcuma ochrorhiza and Curcuma heyneana. Nat. Prod. Res., 2010, 24, 838-845.

[121] Choochote, W.; Chaiyasit, D.; Kanjanapothi1, D.; Rattanachanpichai, R.; Jitpakdi, A.; Tuetun, B.; Pitasawat, B. Chemical composition and anti-mosquito potential of rhizome extract and volatile oil derived from Curcuma aromatica against Aedes aegypti (Diptera: Culicidae). J. Vector Ecol., 2005, 30, 302-309.

[122] Sadhu, S. K.; Tamaki, M.; Ohtsuki, T.; Toume, K.; Koyano, T.; Kowithayakorn, T.; Ishibashi, M. Cadinane Sesquiterpenes from Curcuma parviflora. J. Nat. Prod., 2009, 72.

[123] Zhou, X.; Li, Z. W.; Liang, G. Y.; Zhu, J.; Wang, D. P.; Cai, Z. W. Analysis of volatile components of Curcuma sichuanensis X. X. Chen by gas chromatography-mass spectrometry J. Pharm. Biomed. Anal., 2007, 43.

[124] Al-Reza, S. M.; Rahman, A.; Sattar, M. A.; Rahman, M. O.; Fida, H. M. Essential oil composition and antioxidant activities of Curcuma aromatica Salisb. . Food Chem. Toxicol., 2010, 48, 17571760 .

[125] Kojima, H.; Yanai, T.; Toyota, A. Essential Oil Constituents from Japanese and Indian Curcuma aromatica Rhizomes. Planta Med., 1998, 64, 380-381.

[126] Jayaprakasha, G. K.; Jena, B. S.; Negi, P. S.; Sakariah, K. K. Evaluation of antioxidant activities and antimutagenicity of turmeric oil: a byproduct from curcumin production. Z. Naturforsch, 2002, $57 c, 828-835$.

[127] Zhu, L. F.; Li, Y. H.; Li, B. L.; Ju, B. Y.; Zhang, W. L. Aromatic Plants and Essential Constituents. Hai Feng Publ. Co.: Hong Kong, 1995.

[128] Asghari, G.; Mostajeran, A.; Shebli, M. Curcuminoid and essential oil components of turmeric at different stages of growth cultivated in Iran. Res. Pharm. Sci., 2009, 4, 55-61.

[129] Vabirua-Lechat, I.; Menut, C.; Lamaty, G.; Bessiere, J. M. Huiles essentielles de Polynesia Francais. Numero Speciale, 1996, 627638.

[130] Choudhury, S. N.; Ghosh, A. C.; Saikia, M.; Choudhury, M.; Leclercq, P. A. Volatile constituents of the aerial and underground parts of Curcuma aromatica Salisb. from India. J. Essent. Oil Res., 1996, 8, 633-638.

[131] Rao, J. T.; Nigam, S. S. Essential oil from the rhizomes of Curcuma aromatica Salisb. Flav. Ind., 1974, 5, 234-236.

[132] Bordoloi, A. K.; Sperkova, J.; Lecclercq, P. A. Essential oil of Curcuma aromatica Salisb. from North East India. J. Essent. Oil Res., 1999, 11, 537-540.

[133] Ammon, H. P. T.; Wahl, M. A. Pharmacognosy of Curcuma longa. Planta Med., 1991, 57, 1-7.

[134] Wang, Y. J.; Pan, M. H.; Cheng, A. L.; Lin, L. I.; Ho, Y. S.; Hsieh, C. Y.; Lin, J. K. Stability of curcumin in buffer solutions and characterization of its degradation products. J. Pharm. Biomed. Anal., 1997, 15, 1867-1876.

[135] TØnnesen, H. H.; Karlsen, J.; van Henegouwen, G. B. Studies on curcumin and curcuminoids. IV. Kinetics of curcumin degradation in aqueous solution. Z. Lebensm Unters Forsch, 1985, 180, 402404.

[136] TØnnesen, H. H.; Karlsen, J. Studies on curcumin and curcuminoids. IV. Photochemical stability. Z. Lebensm Unters Forsch., 1986, 183, 116-122.

[137] Qi, L. L.; Wang, J. B. Studies on stability of curcumin. Food Sci. Technol. , 2007, 28, 181-182.

[138] Han, G.; Liu, Z. M.; Wang, X. Y.; Wang, Y. N. Study on effect of different extracts in Curcuma longa on stability of curcumin. Chin. J. Chin. Mat. Med., 2007, 32, 915-917.

[139] Goel, A.; Kunnumakkara, A. B.; Aggarwal, B. B. Curcumin as "Curecumin": From kitchen to clinic. Biochem. Pharmacol., 2008, 75 (4), 787-809.

[140] Price, L. C.; Buescher, R. W. Decomposition of turmeric curcuminoids as affected by light, solvent and oxygen. J. Food Chem., 2007, 20, 125-133.

[141] Oetari, S.; Sudibyo, M.; Commandeur, J. N. M.; Samhoedi, R. Effects of curcumin on cytochrome P450 and glutathione S-
Transferase activities in rat liver. Biochem. Pharmacol., 1996, 51, 39-45.

[142] Chen, Y. H.; Qin, B.; Zhang, Y. Y.; Cheng, W. Comparative study on the process of extraction of curcumin from Curcuma longa $\mathrm{L}$. with different methods. Zhongguo Zhongyi Xinxi Zazhi, 2008, 15, 55-56.

[143] Remya, R.; Syamkumar, S.; Sasikumar, B. Isolation and amplification of DNA from turmeric powder. Br. Food J., 2004, 106, 673678.

[144] Latif, M. A.; Moris, T. R.; Miah, A. M.; Hewitt, D.; Ford, J. E. Toxicity of shoti (Indian arrwroot: Curcuma zedoaria) for rats and chicks. Br. J. Nutr., 1979, 41, 57-63.

[145] Remashree, A. B.; Balachandran, I.; Ravindran, P. N. In Pharmacognostic studies in four species of Curcuma, 12th Swadeshi Sci. Cong., Nov. 6-9, 2003; 2003.

[146] Raghunathan, K.; Mitra, R. Pharmacognosy of indigenous drugs. CCRAS: New Delhi, 1982.

[147] Syamkumar, S.; Sasikumar, B. Molecular marker based genetic diversity analysis of Curcuma species from India. Sci. Hort., 2007, $112,235-241$.

[148] Sasaki, Y.; Nagumo, S. Rapid identification of Curcuma longa and C. aromatica by LAMP. Biol. Pharm. Bull., 2007, 30, 2229-2230.

[149] Minami, M.; Nishio, K.; Ajioka, Y.; Kyushima, H.; Shigeki, K. Kinjo, K.; Yamada, K.; Nagai, M.; Satoh, K.; Sakurai, Y. Identification of Curcuma plants and curcumin content level by DNA polymorphisms in the $\operatorname{trnS}$-trnfM intergenic spacer in chloroplast DNA. J. Nat. Med., 2009, 63, 75-79.

[150] Anuntalabhochai, S.; Sitthiphrom, S.; Thongtaksin, W.; Sanguansermsri, M.; Cutler, R. W. Hybrid detection and characterization of Curcuma spp. using sequence characterized DNA markers. Sci. Hort., 2007, 111, 389-393.

[151] Xia, Q.; Zhao, K. J.; Huang, Z. G.; Zhang, P.; Dong, T. T.; Li, A. P.; Tsim, W. K. Molecular genetic and chemical assessment of Rhizoma Curcumae in China. J. Agric. Food Chem., 2005, 53, 60196026.

[152] Fang, H. Z.; Cui, Y.; Shi, Q.; Zong, X. M. Comparison analysis of chromatographic fingerprints of rhizome curcuma ileum from different species using multivariate resolution methods. Comput. Appl. Chem., 2007, 5.

[153] Herebian, D.; Choi, J. H.; Abd El-Aty, A. M.; Shim, J. H.; Spiteller, M. Metabolite analysis in Curcuma domestica using various GC-MS and LC-MS separation and detection techniques. Biomed. Chromatogr., 2009, 23, 951-965.

[154] Qin, N. Y.; Yang, F. Q.; Wang, Y. T.; Li, S. P. Quantitative determination of eight components in rhizome (Jianghuang) and tuberous root (Yujin) of Curcuma longa using pressurized liquid extraction and gas chromatography-mass spectrometry. J. Pharm. Biomed. Anal., 2007, 43, 486-492.

[155] Zeng, J. H.; Xu, G. B.; Chen, X. Application of the chromatographic fingerprint for quality control of essential oil from GuangXi Curcuma kwangsiensis Med. Chem. Res., 2009, 18, 158165.

[156] Paramasivam, M.; Poi, R.; Banerjee, H.; Bandyopadhyay, A. Highperformance thin layer chromatographic method for quantitative determination of curcuminoids in Curcuma longa germplasm. Food Chem., 2009, 113, 640-644.

[157] Salmén, R.; Pedersen, B. F.; Malterud, K. E. Sudan Red G as an adulterant in turmeric (Curcuma longa L.) Eur. Food Res. Tech., 1987, 184, 33-34.

[158] Di Anibal, C. V.; Odena, M.; Ruisánchez, I.; Pilar Callao, M. Determining the adulteration of spices with Sudan I-II-II-IV dyes by UV-visible spectroscopy and multivariate classification techniques Talanta, 2009, 79, 887-892.

[159] Salmén, R.; Malterud, K. E.; Malterud, K. E.; Pedersen, B. F Structures of the Azo Dyes Sudan Red G [1-(2Methoxyphenylazo)-2-naphthol], $\mathrm{C}_{17} \mathrm{H}_{14} \mathrm{~N}_{2}$, and Sudan Yellow (1Phenylazo-2-naphthol), $\mathrm{C}_{16} \mathrm{H}_{12}$ N. Acta Chem. Scand. A, 1988, 42, 493-499.

[160] Sun, X.; Gao, C.; Cao, W.; Yang, X.; Wang, E. Capillary electrophoresis with amperometric detection of curcumin in Chinese herbal medicine pretreated by solid-phase extraction. J. Chromatogr. A, 2002, 962 (1-2), 117-25.

[161] Wichitnithad, W.; Jongaroonngamsang, N.; Pummangura, S.; Rojsitthisak, P. A simple isocratic HPLC method for the simultaneous determination of curcuminoids in commercial turmeric extracts. Phytochem. Anal., 2009, 20, 314-319. 
[162] He, X. G.; Lin, L. Z.; Lian, L. Z.; Lindenmaier, M. Liquid chromatography-electrospray mass spectrometric analysis of curcuminoids and sesquiterpenoids in turmeric (Curcuma longa). J. Chromatogr. A, 1998, 818, 127-132.

[163] Jiang, H. L.; Timmermann, B. N.; Gang, D. R. Use of liquid chromatography-electrospray ionization tandem mass spectrometry to identify diarylheptanoids in turmeric (Curcuma longa L.) rhizome J. Chromatogr. A, 2006, 1111, 21-31.

[164] Jadhav1, B. K.; Mahadik, K. R.; Paradkar, A. R. Development and validation of improved reversed phase-HPLC Method for simultaneous determination of curcumin, demethoxycurcumin and bisdemethoxycurcumin. Chromatographia, 2007, 65, 483-488.
[165] Lin, X. L.; Xue, L.; Zhang, H. Y.; Zhu, C. F. Determination of curcumins in turmeric by micellar electrokinetic capillary chromatography. Can. J. Anal. Sci. Spect., 2006, 51, 35-42.

[166] Lechtenberg, M.; Quandt, B.; Nahrstedt, A. Quantitative determination of curcuminoids in Curcuma rhizomes and rapid differentiation of Curcuma domestica Val. and Curcuma xanthorrhiza Roxb. by capillary electrophoresis. Phytochem. Anal., 2004, 15, 152-158.

[167] Govindarajan, V. S. Turmeric-chemistry, technology and quality. Crit. Rev. Food Sci. Nutr., 1980, 12, 199-301.

[168] FAO Curcumin. FAO: 2003; pp 1-3.

(C) Li et al.; Licensee Bentham Open.

This is an open access article licensed under the terms of the Creative Commons Attribution Non-Commercial License (http:/creativecommons.org/ licenses/ by-nc/3.0/) which permits unrestricted, non-commercial use, distribution and reproduction in any medium, provided the work is properly cited. 